Prepared in cooperation with the California Department of Water Resources

\title{
Survival, Travel Time, and Utilization of Yolo Bypass, California, by Outmigrating Acoustic-Tagged Late-Fall Chinook Salmon
}

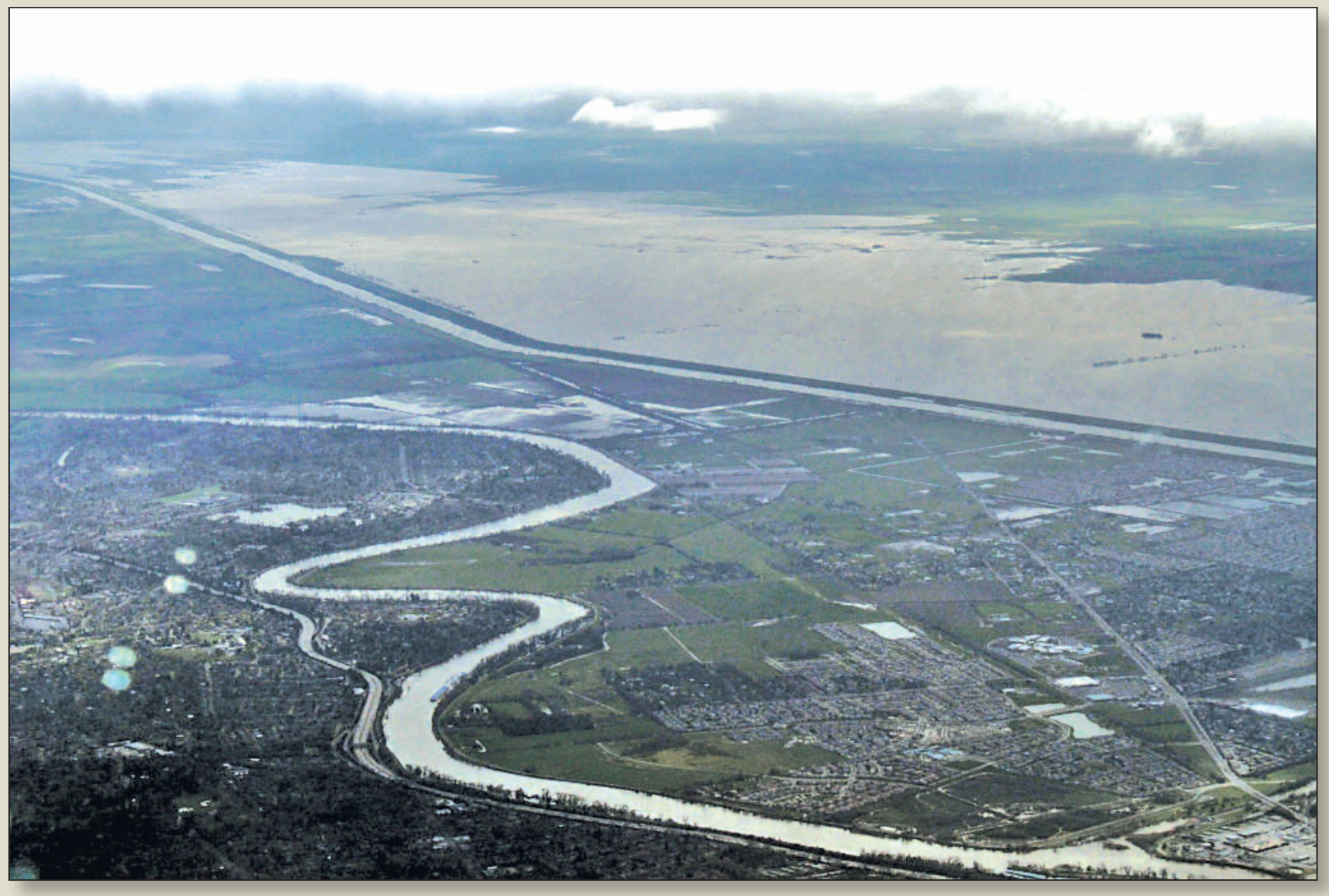

Open-File Report 2018-1118 
Cover: Photograph looking southwest over Yolo Bypass (upper right) diverting flood water around Sacramento, California, parallel with the Sacramento River. Photograph by Chris Austin, Maven's Notebook. 


\section{Survival, Travel Time, and Utilization of Yolo Bypass, California, by Outmigrating Acoustic-Tagged Late-Fall Chinook Salmon}

By Adam C. Pope, Russell W. Perry, Dalton J. Hance, and Hal C. Hansel

Prepared in cooperation with the California Department of Water Resources

Open-File Report 2018-1118

U.S. Department of the Interior

U.S. Geological Survey 


\section{U.S. Department of the Interior \\ RYAN K. ZINKE, Secretary}

\section{U.S. Geological Survey James F. Reilly II, Director}

U.S. Geological Survey, Reston, Virginia: 2018

For more information on the USGS-the Federal source for science about the Earth, its natural and living resources, natural hazards, and the environment-visit https://www.usgs.gov/ or call 1-888-ASK-USGS (1-888-275-8747).

For an overview of USGS information products, including maps, imagery, and publications, visit https:/store.usgs.gov.

Any use of trade, firm, or product names is for descriptive purposes only and does not imply endorsement by the U.S. Government.

Although this information product, for the most part, is in the public domain, it also may contain copyrighted materials as noted in the text. Permission to reproduce copyrighted items must be secured from the copyright owner.

Suggested citation:

Pope, A.C., Perry, R.W., Hance, D.J., and Hansel, H.C., 2018, Survival, travel time, and utilization of Yolo Bypass, California, by outmigrating acoustic-tagged late-fall Chinook salmon: U.S. Geological Survey Open-File Report 2018-1118, 33 p., https://doi.org/10.3133/ofr20181118.

ISSN 2331-1258 (online) 


\section{Contents}

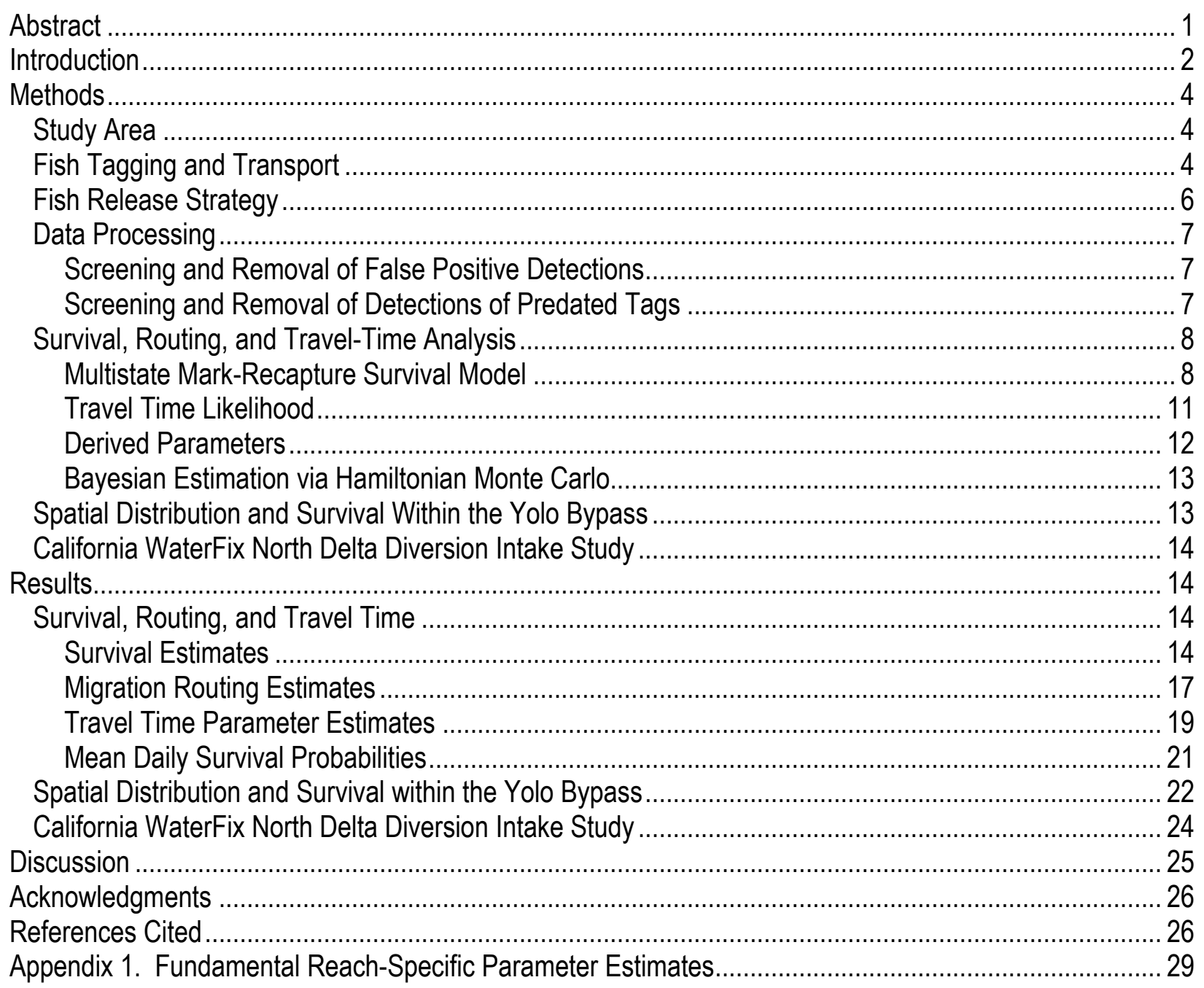

\section{Figures}

Figure 1. Map showing study area, Sacramento-San Joaquin River Delta, California

Figure 2. Instantaneous river flows in Yolo Bypass, in the Sacramento River at Freeport, and in Cache Slough taken at 15-minute intervals, with times of release for each of five release groups

Figure 3. Schematic of the multistate mark-recapture model with parameters indexed by state (migration route) and sampling occasion.

Figure 4. Median probability of survival with upper and lower credible limits (the 5th and 95th percentiles of the posterior distributions for each parameter, respectively) from Fremont Weir to Chipps Island by route through the North Delta, California.

Figure 5. Median probability of entrainment with upper and lower credible limits from Fremont Weir to Chipps Island, California, by route.

Figure 6. Route-specific travel time quantiles from Fremont Weir to Chipps Island, Sacramento-San Joaquin River Delta, California

Figure 7. Cross-stream distribution of tagged fish distribution within Yolo Bypass at the I-80 bridge, separated by release site, California. 


\section{Tables}

Table 1. Dates and numbers of acoustically tagged juvenile Chinook salmon released, Sacramento-San Joaquin River Delta, California.

Table 2. Derived parameters for route-specific overall survival from the Fremont Weir to Chipps Island, Sacramento-San Joaquin River Delta, California.

Table 3. Derived parameters for route-specific entrainment probabilities from the Fremont Weir to Chipps Island, Sacramento-San Joaquin River Delta, California.

Table 4. Derived parameters for route-specific travel times from the Fremont Weir to Chipps Island, Sacramento-San Joaquin River Delta, California.

Table 5. Derived parameters for route-specific daily survival from the Fremont Weir to Chipps Island, Sacramento-San Joaquin River Delta, California..

Table 6. Number of juvenile Chinook salmon used to estimate survival for three Sacramento River reaches encompassing proposed North Delta Diversion intakes in the North Delta, Sacramento-San Joaquin River Delta, California.

Table 7. Median reach-specific and cumulative survival estimates, and 95-percent credible intervals by fish release and reach for the three proposed water-intake sites, Sacramento-San Joaquin River Delta, California. 


\section{Conversion Factors}

International System of Units to U.S. customary units

\begin{tabular}{|c|c|c|}
\hline Multiply & By & To obtain \\
\hline \multicolumn{3}{|c|}{ Length } \\
\hline millimeter (mm) & 0.03937 & inch (in.) \\
\hline meter (m) & 3.281 & foot $(\mathrm{ft})$ \\
\hline kilometer $(\mathrm{km})$ & 0.6214 & mile (mi) \\
\hline kilometer $(\mathrm{km})$ & 0.5400 & mile, nautical (nmi) \\
\hline meter $(\mathrm{m})$ & 1.094 & yard $(\mathrm{yd})$ \\
\hline \multicolumn{3}{|c|}{ Flow rate } \\
\hline cubic meter per second $\left(\mathrm{m}^{3} / \mathrm{s}\right)$ & 70.07 & acre-foot per day (acre-ft/d) \\
\hline meter per second $(\mathrm{m} / \mathrm{s})$ & 3.281 & foot per second $(\mathrm{ft} / \mathrm{s})$ \\
\hline meter per day $(\mathrm{m} / \mathrm{d})$ & 3.281 & foot per day $(\mathrm{ft} / \mathrm{d})$ \\
\hline cubic meter per second $\left(\mathrm{m}^{3} / \mathrm{s}\right)$ & 35.31 & cubic foot per second $\left(\mathrm{ft}^{3} / \mathrm{s}\right)$ \\
\hline cubic meter per second $\left(\mathrm{m}^{3} / \mathrm{s}\right)$ & 22.83 & million gallons per day (Mgal/d) \\
\hline kilometer per hour $(\mathrm{km} / \mathrm{h})$ & 0.6214 & mile per hour $(\mathrm{mi} / \mathrm{h})$ \\
\hline \multicolumn{3}{|c|}{ Mass } \\
\hline $\operatorname{gram}(\mathrm{g})$ & 0.03527 & ounce, avoirdupois (oz) \\
\hline kilogram $(\mathrm{kg})$ & 2.205 & pound avoirdupois (lb) \\
\hline
\end{tabular}

\section{Datums}

Vertical coordinate information is referenced to the North American Vertical Datum of 1988 (NAVD 88).

Horizontal coordinate information is referenced to the North American Datum of 1983 (NAD 83).

\section{Supplemental Information}

Concentrations of chemical constituents in water are given in either milligrams per liter ( $\mathrm{mg} / \mathrm{L})$ or micrograms per liter ( $\mu \mathrm{g} / \mathrm{L})$.

Note to USGS users: Use of hectare (ha) as an alternative name for square hectometer (hm²) is restricted to the measurement of small land or water areas. Use of liter $(\mathrm{L})$ as a special name for cubic decimeter $\left(\mathrm{dm}^{3}\right)$ is restricted to the measurement of liquids and gases. No prefix other than milli should be used with liter.

\section{Abbreviations}

$\begin{array}{ll}\text { CADWR } & \text { California Department of Water Resources } \\ \text { CVP } & \text { Central Valley Project } \\ \text { NDD } & \text { North Delta Diversion } \\ \text { NMFS } & \text { National Marine Fisheries Service } \\ \text { SWP } & \text { California State Water Project } \\ \text { USBR } & \text { U.S. Bureau of Reclamation } \\ \text { USGS } & \text { U.S. Geological Survey }\end{array}$




\title{
Survival, Travel Time, and Utilization of Yolo Bypass, California, by Outmigrating Acoustic-Tagged Late-Fall Chinook Salmon
}

\author{
By Adam C. Pope, Russell W. Perry, Dalton J. Hance, and Hal C. Hansel
}

\begin{abstract}
Juvenile Chinook salmon (Oncorhynchus tshawytscha) migrating through California's Sacramento-San Joaquin River Delta toward the Pacific Ocean face numerous challenges to their survival. The Yolo Bypass is a broad floodplain of the Sacramento River that floods in about 70 percent of years in response to large, uncontrolled runoff events. As one of the routes juvenile salmon may utilize, the Yolo Bypass has recently received attention for having potential benefit to rearing and migrating salmon. Consideration is being given to a plan to build a cut or "notch" in the Fremont Weir to increase juvenile salmon access to the Yolo Bypass. To help provide information about the potential benefit of such a plan, we analyzed data from a telemetry study conducted in February and March 2016 by the U.S. Geological Survey and California Department of Water Resources to estimate entrainment into and distribution of juvenile Chinook salmon within the Yolo Bypass, and to compare survival and travel time through the Yolo Bypass to other routes in the Delta. We also estimated juvenile Chinook salmon survival through three short reaches of the Sacramento River where the proposed California WaterFix North Delta Diversion intakes would divert water to export facilities to provide baseline information against which any effects of those intakes could be measured in the future.

We found that entrainment into the Yolo Bypass varied widely and was quite high only at the peak of the March 2016 flood. Spatial distribution of juvenile Chinook salmon within the Yolo Bypass was fairly even for fish entering the Yolo Bypass over the Fremont Weir, but increasingly skewed toward the east bank for fish released within the Yolo Bypass. Survival within Yolo Bypass was not significantly different for fish based on spatial distribution. Survival through the Delta for fish migrating through the Yolo Bypass was generally on par with the weighted survival through the Delta of fish migrating through all other routes. Survival was highest for fish remaining in the Sacramento River and lowest for those entrained into the Interior Delta via Georgiana Slough. Survival through the short section of the Sacramento River near the proposed North Delta Diversion intakes was high.
\end{abstract}




\section{Introduction}

Juvenile Chinook salmon (Oncorhynchus tshawytscha) migrating from their natal tributaries toward the Pacific Ocean are subject to numerous factors affecting their migration timing, migration route, and survival. Several factors are influenced by the regulation of rivers through which these fish migrate. For example, flow regulation can impact river temperature and turbidity, which can in turn affect availability of thermal refugia or exposure to predation (Raymond, 1988; Smith and others, 2003). Diversion of flows can influence the migration route used by juvenile salmon, which can ultimately influence overall population survival if there is a substantial difference in survival among routes (Skalski and others, 2002; Perry and others, 2015). Understanding the mechanisms by which migration timing, route selection, and survival are affected, either directly or indirectly, by the regulation of river systems can help managers make decisions that are more likely to benefit these populations.

The Sacramento-San Joaquin River Delta (hereafter, "Delta") in the Central Valley of California is a network of both natural and man-made channels connecting the Sacramento and San Joaquin Rivers with the San Francisco Bay on their way toward the Pacific Ocean (fig. 1). Juvenile salmon migrating downstream through the Sacramento River must navigate the Delta on their seaward journey. The Delta also supports both the Central Valley Project (CVP) and California State Water Project (SWP), which supply agricultural and drinking water to much of California by diverting river water to aqueducts via pumping stations in the southern Delta.

Several factors affect juvenile salmon survival during migration, either directly or indirectly. Since navigation through the Delta affords multiple routes, the route travelled is important in determining the probability a fish survives to reach the ocean. For example, predator density in the Delta is thought to vary among migration routes (Turner and Chadwick, 1972; Nobriga and others, 2005), driving variation in route-specific survival. Likewise, survival can be affected indirectly through the amount of time it takes for a fish to navigate through the Delta. For instance, a fish that remains in the mainstem Sacramento River is likely to reach San Francisco Bay sooner than one that enters Georgiana Slough, which diverts fish to the "Interior Delta" (the region to the south of the mainstem Sacramento River; fig. 1) where tidal influences, multiple side channels, and water-pumping stations can each act to disorient and slow migrating fish (Brandes and McLain, 2001; Newman and Brandes, 2010; Perry and others, in press). 
One potential route for downstream migrating juvenile salmon is the Yolo Bypass, a broad floodplain (64-km-long and 4.8-km-wide) of the Sacramento River that floods in about 70 percent of years in response to large, uncontrolled runoff events (Sommer and others, 2008). Studies have suggested that access to the Yolo Bypass floodplain habitat can increase fitness and survival of migrating juvenile salmon (Sommer and others, 2001a, 2001b, 2005). In addition to accessing highquality rearing habitat, juvenile salmon entrained into the Yolo Bypass avoid migration through the Interior Delta, where survival has been shown to be significantly lower than for other routes (Perry and others, 2010, 2013). As a result, consideration is being given to providing an intake or "notch" in the Fremont Weir as a management action to benefit salmon populations in the Sacramento River under Yolo Bypass Salmonid Habitat Restoration and Fish Passage Implementation Plan (U.S. Bureau of Reclamation and California Department of Water Resources, 2012). Fremont Weir is a 2.9-km-long concrete structure that, when overtopped by the Sacramento River, leads to flooding of the Yolo Bypass, providing access to juvenile salmon. However, there is little direct information available on how migrating salmon utilize the Yolo Bypass, including the proportion of fish entering Yolo Bypass, survival within the bypass, and the spatial distribution of fish migrating through the Yolo Bypass.

In addition to serving as the migratory pathway for juvenile anadromous fishes, the Delta is also the hub of California's water delivery system. California WaterFix is a proposed multi-billiondollar Sacramento River water project designed to update the SWP and coordinated operations of the CVP. The WaterFix Project proposal includes the construction of three water diversion intakes named the North Delta Diversion intakes, among other proposed new infrastructure. The new intakes would be located on the east bank of the Sacramento River at river kilometers (rkms) 66.1, 63.4, and 59.2 (fig. 1). Together, the intakes would be capable of diverting a maximum combined total flow of 254.9 $\mathrm{m}^{3} / \mathrm{s}\left(9,000 \mathrm{ft}^{3} / \mathrm{s}\right)$. The intakes would include state-of-the-art fish screens to minimize fish entrainment and enable the SWP and CVP to coordinate South and North Delta facilities operations in a way that would enhance protective measures for native fish. The water diverted by the intakes would be carried 30 miles by two 40-foot-diameter underground pipelines to the Clifton Court Forebay where two proposed pumping plants would be built to maintain optimum water levels in the forebay for the existing SWP and CVP pumping facilities (ICF International, 2016). Baseline information on survival of juvenile salmon through the proposed intake reaches will provide important context to future management.

To provide information on the potential benefit of management actions that increase salmonid access to Yolo Bypass, the U.S. Geological Survey (USGS), in cooperation with CADWR, undertook a telemetry study using acoustically tagged juvenile Chinook salmon to estimate the probability of entrainment through a project notch and survival within the Yolo Bypass before, during, and after a flood event during the migration season of 2016. To maximize the utility of this study, we used data arising from the study for three distinct objectives: (1) to estimate and compare route-specific survival and travel time of juvenile Chinook salmon utilizing the Yolo Bypass to that of fish using other available routes in the North Delta during the same period of time; (2) to determine the spatial distribution and difference in survival of fish along an east-west gradient within the Yolo Bypass; and, (3) to evaluate fine-scale reach-to-reach survival of Chinook salmon remaining in the mainstem Sacramento River in the vicinity of the proposed California WaterFix North Delta Diversion intakes. 


\section{Methods}

\section{Study Area}

We evaluated the potential benefit of the Yolo Bypass to migrating juvenile salmon in the context of the branching network of channels of the North Sacramento-San Joaquin Delta. Multiple migration routes are available to juvenile salmon migrating oceanward through the North Delta. In addition to remaining in the mainstem Sacramento River, fish may utilize one or more alternative migration routes. The Yolo Bypass begins at the Sacramento River just upstream from Verona at the Fremont Weir. When the weir is overtopped, fish can be entrained into the Yolo Bypass, which rejoins the Sacramento River near Rio Vista via Cache Slough. Sutter and Steamboat Sloughs diverge from the mainstem Sacramento River downstream from Freeport, subsequently connect via Miner Slough and, like the Yolo Bypass, rejoin the Sacramento River near Rio Vista. For fish that remain in the Sacramento River, subsequent divergences are the Georgiana Slough and, when its radial gate is open, the Delta Cross Channel near Walnut Grove. These two channels join the Mokelumne River, the lower San Joaquin River, and the channels of the Interior Delta, which in turn lead to either of the CVP or SWP export facilities or rejoin the Sacramento River near Chipps Island (fig. 1).

A network of acoustic telemetry stations were deployed throughout the North Delta to monitor acoustically tagged juvenile salmon as they migrated to the ocean. Each telemetry station consisted of one or more acoustic tag detecting hydrophones (Vemco, Ltd.; Models VR2W, HR2). The number of hydrophones deployed at each station varied depending on the number needed to maximize detection probability. Except for Yolo Bypass, hydrophones were located just downstream of each major channel junction in each route. No hydrophones were deployed in the Yolo Bypass immediately below its entrance via Fremont Weir due to logistical challenges associated with monitoring the entire length of Fremont Weir. Instead, an array of hydrophones was deployed along the Interstate 80 bridge (hereinafter, "I-80") across the section flooded by the Yolo Bypass (fig. 1). Additional hydrophones were located at exits of migration routes, including where Sutter Slough, Steamboat Slough, and the Yolo Bypass rejoin the Sacramento River, as well as at the exit of Georgiana Slough into the Mokelumne River (fig. 1). Multiple hydrophones were deployed in the Sacramento River near Chipps Island to form a pair of detection arrays at the study area's furthest downstream point. Finally, multiple hydrophones were in the Sacramento River between Freeport and the junction with Sutter Slough. These stations were positioned to bracket each of three proposed sites for the California Waterfix North Delta Diversion intakes (fig. 1).

\section{Fish Tagging and Transport}

Juvenile, late-fall run Chinook salmon reared at the U.S. Fish and Wildlife Service Coleman National Fish Hatchery in Anderson, California, were obtained for this study. Fish were held at the hatchery until just prior to tagging, when they were transported to the tagging facility at the Sutter Mutual Water Company pumping facility in Robbins, California, at the Tisdale Weir on the Sacramento River, approximately $57 \mathrm{rkms}$ upstream of the Fremont Weir. Each fish was anaesthetized, individually weighed and measured, and surgically implanted with an acoustic transmitter (Vemco, Ltd.; Model V5). Fish were screened and selected for tagging only if their weight exceeded $13 \mathrm{~g}$ so that anticipated tag burden would be less than 5 percent. After being allowed to recover from surgery in river water supersaturated with oxygen for at least 10 minutes, tagged fish were held without further handling for 15-38 hours and then were transported for release. Measurements of tagged and released fish ranged from 108 to $218 \mathrm{~mm}$ in fork length and from 13.4 to $116.8 \mathrm{~g}$ in weight, with means of $165.3 \mathrm{~mm}$ and $50.0 \mathrm{~g}$. Tagging and transport procedures are further detailed by Liedtke and Hurst (2017). 


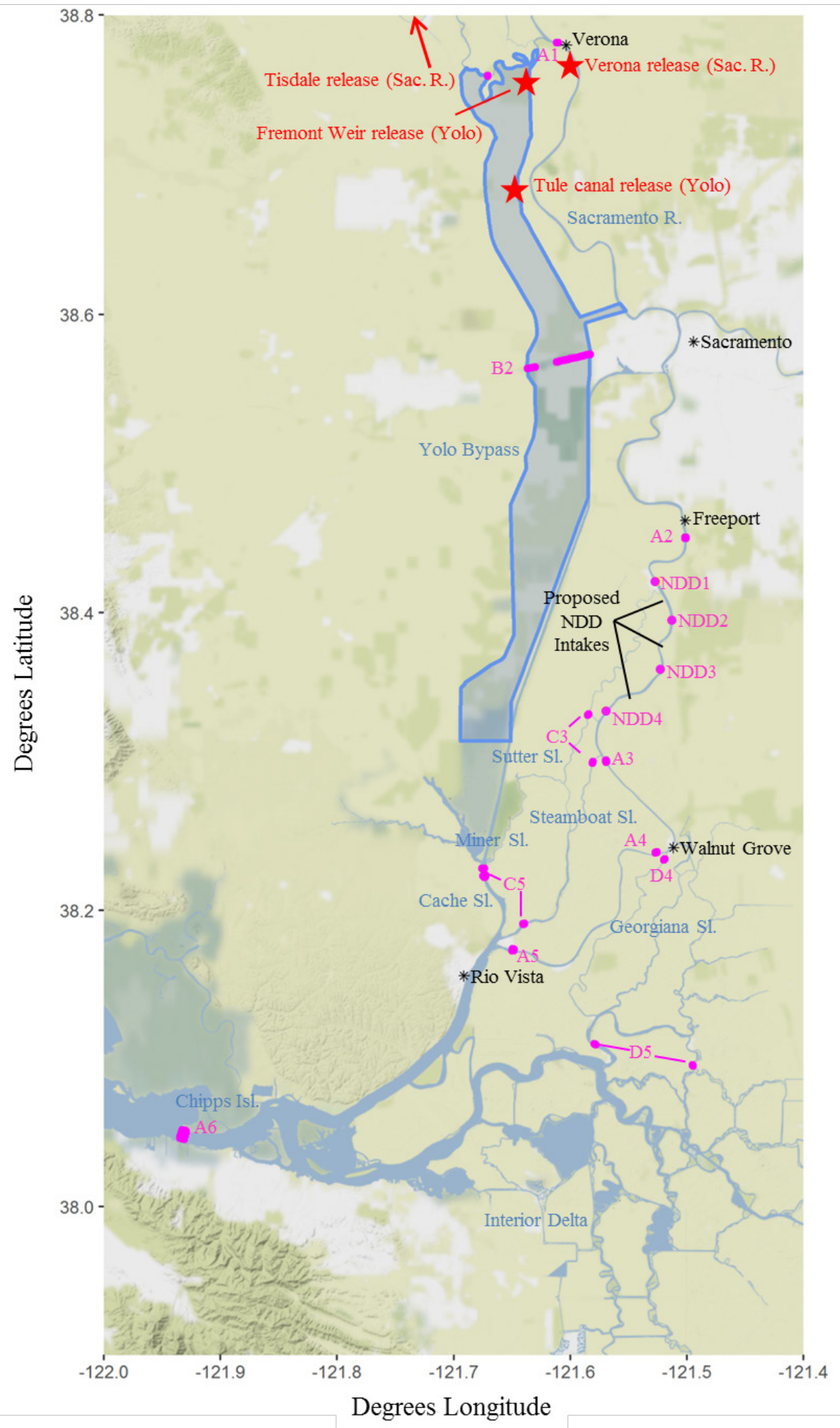

Figure 1. Map showing study area, Sacramento-San Joaquin River Delta, California. (Telemetry stations used for Delta-wide estimates are labeled with dots. The four telemetry stations which bracket the three proposed North Delta Diversion (NDD) intakes and were used to estimate NDD intake area survival were not used in the Deltawide survival model. Place names are included for reference. The Yolo Bypass, indicated by the shaded polygon, is only sometimes flooded.) 


\section{Fish Release Strategy}

A major objective of this study was characterizing fish behavior at the Fremont Weir and utilization of the Yolo Bypass over a wide range of hydrologic variability. These conditions include river flows insufficient to overtop the Fremont Weir as well as the ascending limb, peak, and descending limb of flood pulse discharges sufficient to cause overtopping of Fremont Weir and inflow into the Yolo Bypass. As such, planning fish-release timing and location was approached with an adaptive management strategy. These decisions were made by a small team of agency representatives knowledgeable in either the hydraulics of the Sacramento River/Sutter/Yolo Bypass system during high flows or in the movements of juvenile salmon in this region. Release timing was determined by monitoring the weather, hydrologic forecasts, and discharge data collected in the upper Sacramento River basin.

Five releases were conducted, for a total of 1,197 tagged fish released (table 1). The first two releases of 240 tagged fish occurred during flows insufficient to overtop the Fremont Weir and were intended primarily to document the distribution of fish as they passed Fremont Weir. These releases were focused on attempting to determine the effect of secondary circulation in concentrating fish density on the outside of bends (Blake and others, 2017). In this study phase, we targeted stages of $18-$ $25 \mathrm{ft}$ NAVD88 during the ascending limb of the hydrograph, but prior to flow into the Yolo Bypass over the Fremont Weir. These stages were reflective of potential periods in which a notch could operate based on design considerations at the time of the study.

Table 1. Dates and numbers of acoustically tagged juvenile Chinook salmon released, Sacramento-San Joaquin River Delta, California.

\begin{tabular}{llccc}
\hline $\begin{array}{c}\text { Release } \\
\text { group }\end{array}$ & Date(s) & $\begin{array}{c}\text { Number } \\
\text { released } \\
\text { at Tisdale }\end{array}$ & $\begin{array}{c}\text { Number } \\
\text { released } \\
\text { into Yolo } \\
\text { Bypass }\end{array}$ & $\begin{array}{c}\text { Number } \\
\text { released } \\
\text { at Verona }\end{array}$ \\
\hline 1 & February 21 & 240 & 0 & 0 \\
2 & March 6 & 240 & 0 & 0 \\
3 & March 11-12 & 141 & 99 & 0 \\
4 & March 15-16 & 40 & 100 & 100 \\
5 & March 17-18 & 40 & 98 & 99 \\
\hline
\end{tabular}

The final three releases of approximately 240 tagged fish were conducted to study passage in the Yolo Bypass during: (1) initial over topping, (2) peak flow into the Bypass, and (3) descending limb of bypass flooding (fig. 2). During periods when the Fremont Weir was overtopped (Release Groups 4 and 5), we released approximately 40 study fish upstream of the Fremont Weir at Tisdale Weir to determine rates of entrainment into the bypass. Approximately 100 fish were released directly into the Yolo Bypass as close as possible to the Fremont Weir and 100 fish into the Sacramento River just downstream of the Fremont Weir to assure an adequate sample size for downstream receivers in both the Yolo Bypass and in the North Delta survival arrays, regardless of entrainment rate into the bypass (table 1). Fish released into the Yolo Bypass during Release Group 3 were released into the Tule Canal just upstream of I-5 since the Fremont Weir had not yet overtopped and flows were too low within the Yolo Bypass just downstream of the weir (fig. 1). Each release was timed to distribute released fish as evenly as possible over a single 24-hour period as they passed downstream of the Fremont Weir. For example, for a release group in which fish were released at Tisdale Weir, Fremont Weir, and into the Yolo Bypass, there was a delay between the Tisdale release and the other release sites as to allow the upstream-released fish time to migrate to the Fremont Weir. In this way, all fish within a release group would to a large extent experience similar hydrologic conditions. 


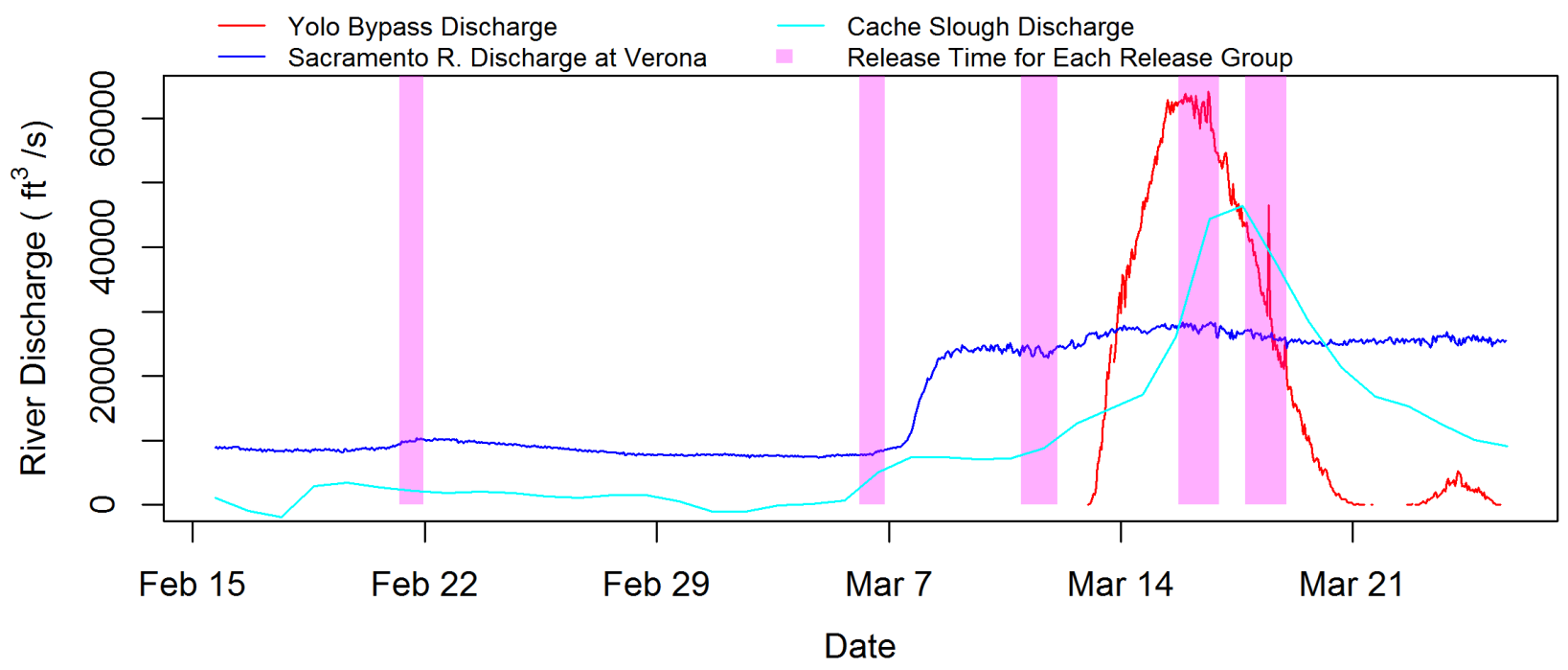

Figure 2. Instantaneous river flows in Yolo Bypass (red), in the Sacramento River at Freeport (dark blue), and in Cache Slough (light blue) taken at 15-minute intervals, with times of release (pink) for each of five release groups. (ft $3 / \mathrm{s}$, cubic foot per second)

\section{Data Processing}

Data downloaded from the Vemco acoustic telemetry receivers consisted of individual detected pulses, uniquely identifiable by tag. Data were post-processed and filtered into a form suitable for subsequent analyses.

\section{Screening and Removal of False Positive Detections}

Acoustic receivers are susceptible to interpreting ambient or mechanical acoustical noise as tag detections. In the case of Vemco receivers, individual pulses recorded by the datalogger have a small chance of not having originated from the designated tag. These false positive detections were screened from the data by requiring at least two independent pulses from a given tag at the same location within a 30-minute period in order to be considered a valid detection. Single pulses not meeting these criteria were filtered from the data and disregarded in further analyses.

\section{Screening and Removal of Detections of Predated Tags}

Mark-recapture analysis relies on the assumption that detections represent live, tagged individuals. As such, it is critical to screen for and remove detections of tags implanted in juvenile salmon smolts which may have been eaten by piscivorous predators, since treating these detections as having originated from live smolts would result in positively biased survival estimates.

Detections of tags that may have been consumed by predators were identified and removed from the data set by hierarchical cluster analysis following the adapted methods of Gibson and others (2015) as reported in California Department of Water Resources (2016). This process consisted of several steps involving application of clustering to several movement metrics, identification of clusters with evidence of predation, and review of detection histories to identify when suspected predation occurred. Detections of tags from known predators were included within the cluster analyses, which 
allowed examination of how movements of known predatory fishes were grouped with putative predators of tagged juvenile Chinook salmon.

The metrics selected for use in the hierarchical cluster analysis were as follows:

1. Total elapsed time between first detection after release and last detection, in days (ArrayTime);

2. Number of consecutive detection events occurring at the same location (NSame);

3. Total distance travelled divided by the total number of days spent in the array (PathDays); and

4. Number of transitions that were deemed to be only possible by a predator (that is, movement upstream against the flow) (NPred).

ArrayTime was calculated by subtracting the time of first detection after a tag was released from the time of last detection for that tag. NSame was calculated as the total number of detection events from a single tag that occurred at the same site consecutively. PathDays was estimated by summing the total distance travelled within the array and dividing the distance by the total time the fish was in the array (release time to last detection time). NPred was calculated by summing the number of predator-like transitions that occurred in a detection history. Predator-like transitions were defined as upstream movements between telemetry locations that could only have occurred by fish swimming against downstream river flow, which would be extremely unlikely behavior for juvenile Chinook salmon. All metrics were standardized to have a mean of zero and a standard deviation of one.

The h-clust package in $\mathrm{R}$ was used to create a dendrogram of all the tags from the results of hierarchical clustering, based on Ward's minimum variance method (Ward, 1963; Gibson and others, 2015). Using the dendrogram, the tags were divided into three groups, and then the group with most of the known predator tags was selected for further scrutiny. Any juvenile Chinook salmon tag that was assigned to this group was considered to exhibit behavioral patterns consistent with that of predators. Although this approach identified putative predators, it did not identify the point in the detection history at which the juvenile Chinook salmon was consumed. Therefore, all detection histories of juvenile Chinook salmon tags that were grouped with predators were manually examined to identify the point in the detection history where the tag transitioned from juvenile Chinook salmon- to predator-like behavior.

Screening of the detection data for potential predator detections via hierarchical cluster analysis resulted in 220 tag detection records flagged for review. All known predator tags with more than a single detection event fell into the same group as the smolt tags flagged for review. Manual review of each of the detection histories resulted in 16 tags determined to have been predated during the time each was active in the acoustic array. All 16 tag detection histories were truncated at the point we determined the tag had been predated, and subsequent detections were censored from further analysis.

\section{Survival, Routing, and Travel-Time Analysis}

\section{Multistate Mark-Recapture Survival Model}

We designed a statistical model to estimate reach- and route-specific survival for primary outmigration routes through the Delta (fig. 3). We used the general framework of multistate markrecapture modelling to estimate the parameters of interest (Lebreton and others, 2009). Here, the term "state" refers to the fact that juvenile salmon migrating through the Delta do so through one or more routes. Fish can transition between these routes at discrete junctions, and their survival is dependent on which route they take to traverse the study area. Routes include the Sacramento River (Route A), Yolo Bypass (Route B), Sutter and Steamboat sloughs (Route C), and the Interior Delta via Georgiana Slough (Route D). Hydrophone monitoring locations were selected so that survival within these four routes was estimable (fig. 1). 


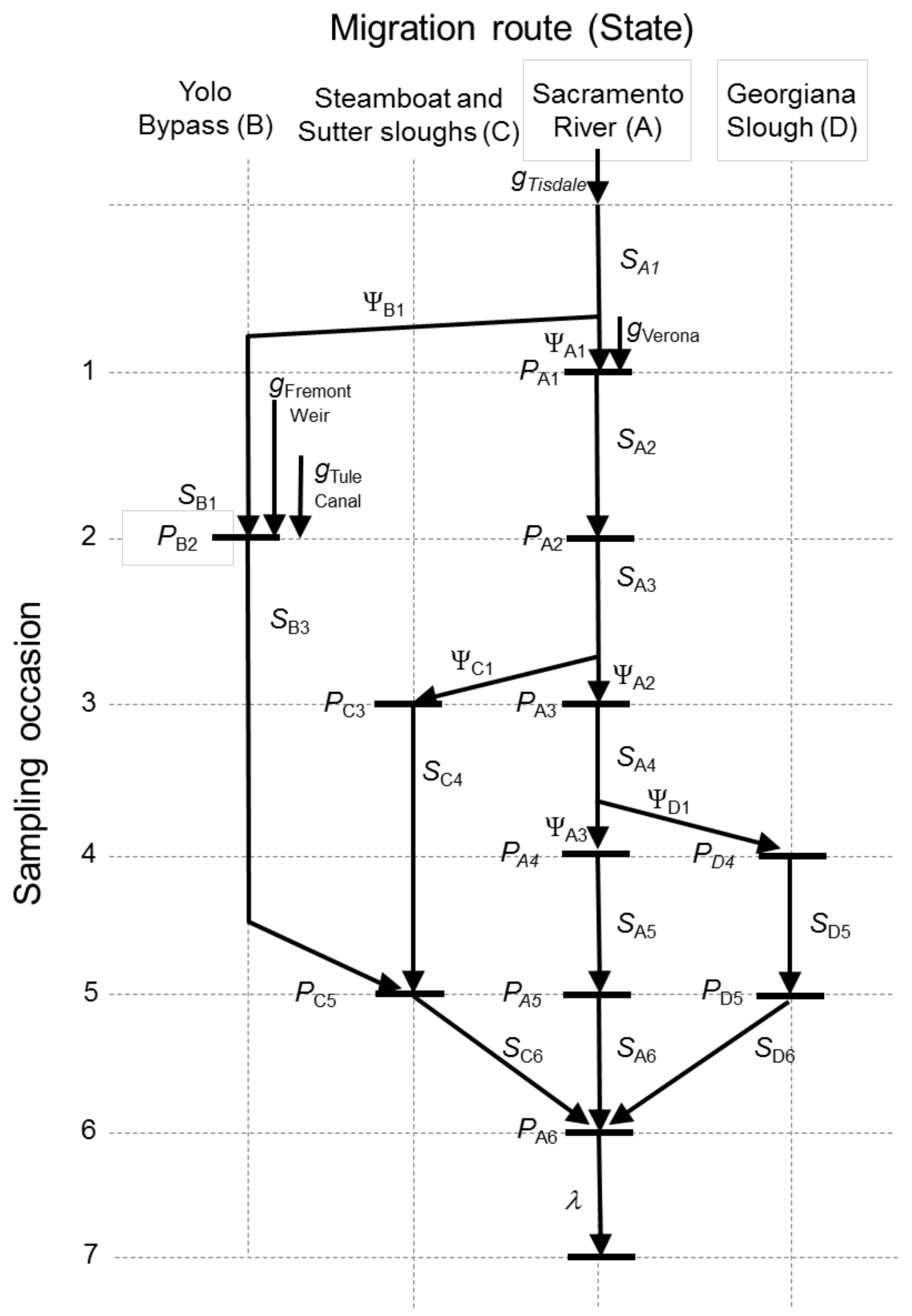

Figure 3. Schematic of the multistate mark-recapture model with parameters indexed by state (migration route) and sampling occasion. (Parameters include reach-specific survival probabilities [S], site-specific detection probabilities $[P]$, routing probabilities $[\psi]$, and $\lambda$, the joint probability of surviving and being detected at telemetry stations downstream of site A6. Release locations are indicated $[g]$ ). 
The mark-recapture model that is shown in fig. 3 estimates the following three types of parameters from detections of tagged juvenile Chinook salmon:

$S_{j t} \quad$ Survival Probability, defined as the probability of surviving from telemetry station $t-1$ within route $j$ to telemetry station $t$ (that is, to the next downstream telemetry station);

$\psi_{j t} \quad$ Route Entrainment Probability, defined as the probability of entering route $j$ at occasion $t$, conditional on surviving to occasion $t$; and

$P_{j t} \quad$ Detection Probability, defined as the probability of detecting a tagged fish at telemetry station $t$ within route $j$, conditional on fish and tags surviving to telemetry station $j t$. All parameters were estimated independently for each of the five releases described earlier. Subscripting by release is omitted throughout this section for ease of reading. While most survival probabilities used in our model represent survival within a given reach of a single channel, some survival parameters represent the average survival of fish migrating through several possible unmonitored channels. For example, $S_{C 4}$ (fig. 3) represents the average survival of fish migrating through the combination of Sutter, Steamboat, and Miner Sloughs, weighted by the unknown number of fish using each possible route.

To estimate these parameters, telemetry data first were summarized into alpha-numeric codes called a "capture history" that compactly represented each fish's movement history through the telemetry network by indicating detections at each telemetry station. In the case of the model shown in fig. 3, each capture history would be seven digits/letters long, one for each sampling occasion. Each individual letter represents detection within a specific route at that sampling occasion, with a 0 denoting no detection. As an example, consider the capture history "AA00DAA." This tag would have been detected in Route A on sampling occasions 1 and 2, not detected on sampling occasions 3 and 4, detected in Route D on sampling occasion 5, and in Route A again on sampling occasions 6 and 7 (figs. 1,3). Of note in this example is that migration routing can sometimes be inferred even when fish were not detected; here we know that the fish remained in the Sacramento River at the junction with Sutter and Steamboat Sloughs, and subsequently migrated through Georgiana Slough into the Interior Delta, since it was detected at location D5 at the base of the Mokelumne River.

Each capture history is viewed as one possible outcome from a multinomial distribution and has an associated probability of occurrence defined as a function of the model parameters. This likelihood function has the form:

$$
L\left(\psi, S, P \mid R, n_{m}\right) \propto \prod_{m \in M} \pi_{m}^{n_{m}}
$$

where $M \quad$ is the set of all possible capture histories;

$R \quad$ is the number of fish released;

$n_{m} \quad$ is the number of fish with capture history $m$; and

$\pi_{m} \quad$ is the multinomial cell probability for capture history $m$, defined in terms of parameters $\psi, S, P$. 
The equation for $\pi_{m}$ is:

$$
\pi_{m}=\prod_{t=F_{m}}^{L_{m}} \sum_{j \in J_{m t}} \psi_{j t} S_{j t} \theta_{j t} \times \chi_{L_{m}},
$$

where $J_{m t} \quad$ is the set of possible routes available at occasion $t$ given capture history $m$;

$F_{m} \quad$ is the occasion of first possible detection after release for capture history $m$;

$L_{m} \quad$ is the occasion of last detection for capture history $m$;

$\theta_{j t} \quad$ represents $P_{j t}$ for route $j$ and occasion $t$ if capture history $m$ indicates detection in route $j$ and occasion $t$, and represents $1-P_{j t}$ otherwise; and

$\chi_{L_{m}} \quad$ represents the probability of not being detected after occasion $t=L_{m}$.

The parameter $\chi_{t}$ is defined recursively (Cormack, 1964); $\chi_{T}=1$ for the final occasion $T$ (here, $T=7$, downstream from Chipps Island) since there are no opportunities to detect fish after the final occasion, and

$$
\chi_{t}=\chi_{t+1} \times \sum_{j \in J_{n t}} \psi_{j}\left(S_{j t}\left(1-P_{j t}\right)+\left(1-S_{j t}\right)\right)
$$

for occasions $t \in\{1, \ldots, T-1\}$.

\section{Travel Time Likelihood}

For each tagged fish, the time of release and each subsequent time of detection was recorded. These recorded detection times were converted so that each detection provided the time elapsed since the previous detection. Recalling the previous example capture history "AA00DAA," travel time data consists of five elapsed travel times, associated with each of the five detections in the capture history. The first time represents time elapsed from release to first detection at telemetry station A1 in this example. When one or more consecutive detections are missed, the next detection is associated with the cumulative elapsed time over multiple reaches since the last prior detection. In our example, the time associated with the detection " $\mathrm{D}$ " in the fifth digit represents elapsed time from detection at A2 to detection at D5.

These elapsed travel time data were analyzed to estimate independent travel time parameters for each adjacent pair of release/acoustic telemetry locations. For each reach, travel times were modeled as arising from a gamma distribution. Thus, for a reach in route $j$ from occasion $t$ to occasion $t+1$, the likelihood of the recorded elapsed travel time between these two stations is defined by the following equation:

$$
L\left(\alpha_{j t}, \beta \mid \tau_{i t}\right) \propto \tau_{i t}^{\alpha_{j t}-1} e^{-\beta \tau_{i t}},
$$

where $\tau_{i t}$ is the recorded travel time for individual $i$ from occasion $t$ to occasion $t+1$. 
While this approach of estimating travel time parameters for individual reaches defined by adjacent telemetry stations produces unbiased estimates, the model by itself does not make use of all the information in the recorded data. When detections are missing, there is no data available for that individual to directly model travel times for the reaches immediately upstream and downstream of the missing detection since we do not know when that fish arrived. However, using a property of the gamma distribution, namely that the sum of gamma distributed random variables is itself gamma distributed when each of the random variables has the same parameter $\beta$, we can indirectly parameterize partially missing travel time data. In our example, we have recorded time elapsed from station A2 to D5. This represents the sum of the times from A2 to A3, A3 to D4, and D4 to D5. The sum of gammas property then results in the ability to easily model elapsed travel times between nonadjacent telemetry stations. The overall travel time likelihood is therefore:

$$
L(\alpha, \beta \mid R, \tau) \propto \prod_{i=1}^{R} \prod_{t \in \tau_{i}} \sum_{j \in J_{i t}} \psi_{j t} \times \operatorname{gamma}\left(\alpha_{j t}, \beta\right),
$$

where $\tau_{i} \quad$ is the set of recorded travel time pairs for individual $i$;

$J_{i t} \quad$ is the set of all routes available for individual travel time pair $\tau_{i t}$; and

$\operatorname{gamma}(\alpha, \beta) \quad$ is the pdf of a gamma random variable detailed in eq. 1.4.

\section{Derived Parameters}

Fundamental parameters were estimated under this likelihood at the reach scale (that is, over the region bounded by adjacent telemetry stations). However, other parameters of interest are on a different spatial scale as these fundamental reach-specific parameters. For example, route-specific survival is defined as total overall survival from the release point at Tisdale downstream to Chipps Island for fish traversing a specific route which generally encompasses multiple reaches. This routespecific survival is defined as the product of individual reach-specific survival parameters that comprise the route. Likewise, the probability of migrating through a specific route is not the same as that of initially entering the route if there are multiple junctions within that route. This overall route entrainment probability is defined as the product of the entrainment probabilities for each junction along that route. Overall Delta-wide survival from release at Tisdale to Chipps Island can be calculated as the sum of the route-specific survival probabilities, weighted by the route entrainment probabilities. Since we wish to compare survival through the Yolo Bypass to survival for all other routes, we can similarly calculate non-Yolo Bypass survival, omitting route entrainment and route-specific survival for the Yolo Bypass route from this calculation. Finally, we also calculate a daily survival for fish migrating via each major route, as well as for fish migrating via any of the non-Yolo Bypass routes. Daily survival is calculated by taking the $E\left[\tau_{\text {Route }_{j}}\right]$ th root of survival for a given route from the Fremont Weir to Chipps Island, where $E\left[\tau_{\text {Route }_{j}}\right]$ is the expected travel time for Route $_{j}$ in days. 
Specifically,

$S_{\text {Route }_{j}} \quad$ represents survival from the Fremont Weir to Chipps Island for Route , $_{\text {, }}$

and is calculated by taking the product of reach-specific survivals that trace a unique migration route through the Delta;

$\psi_{\text {Route }_{j}} \quad$ represents overall entrainment probability for Route $e_{\text {, }}$, and is calculated by

taking the product of junction-specific entrainment probabilities along that route;

$S_{\text {non-Yolo }}=\sum_{j \in\{A, C, D\}} \psi_{\text {Route }_{j}} S_{\text {Route }_{j}}$ represents non-Yolo overall survival;

$S / D_{\text {Route }_{j}}=S_{\text {Route }_{j}} \sum_{t=1}^{\frac{\beta}{T} \alpha_{j t}}$ represents daily survival for fish migrating via Route $_{j}$; and

$S / D_{\text {non-Yolo }}=\sum_{j \in\{A, C, D\}} \psi_{\text {Route }_{j}} S / D_{\text {Route }_{j}}$ represents non-Yolo daily survival;

where $J \in\{A, B, C, D\}$ is one of the possible routes through the Delta from the Fremont Weir to Chipps Island, and the Yolo Bypass is part of Route $B$.

\section{Bayesian Estimation via Hamiltonian Monte Carlo}

All parameters were estimated simultaneously using Hamiltonian Monte Carlo (HMC) methods using the Stan modeling software package (Carpenter and others, 2017). The observed travel times and capture history of each tagged individual comprised all data whose total likelihood was expressed as the product of the survival and travel time likelihoods described above. Standard normal prior

distributions were placed on the transformed travel time parameters $\log \left(\alpha_{j t} / \beta\right)$, and all other parameters were given default implicit priors by the Stan software. Four separate HMC chains were run in Stan for 2,000 iterations each, discarding the first 1,000 as burn-in. Posterior samples were checked for convergence and mixing, and the resulting sample of 4,000 draws was then reported via median, 5th and 95th percentiles for each parameter estimated. Derived parameters were calculated by creating a new posterior sample for each derived parameter. This was achieved by using the formula for a derived parameter across each of the 4,000 sample draws. The medians and credible intervals reported for these derived parameters are thus the corresponding quantiles of these derived posterior samples.

\section{Spatial Distribution and Survival Within the Yolo Bypass}

The cross-stream distribution of acoustic-tagged fish in the Yolo Bypass was estimated at the point where I- 80 crosses the bypass just west of the city of Sacramento. A total of 19 hydroacoustic receivers were deployed on the south side of two sections of roadway bridging the bypass, separated by an island (fig. 1). The location of each fish in the bypass was defined as the distance in meters from the I-80 bridge receiver at the eastern most end of the array to the receiver where the fish was first detected. The first group of receivers monitoring the east bridge section was comprised of 15 receivers ranging from 0 to $2,559 \mathrm{~m}$ from the east bank of the bypass. The second group of four receivers on the west bridge section ranged from 4,231 to 4,812 $\mathrm{m}$ distant. The receivers within both groups were generally about $200 \mathrm{~m}$ apart, but in a few cases were more closely spaced. A Gaussian kernel density function was applied to the data using $\mathrm{R}$ to estimate the horizontal density of fish across the bypass ( $\mathrm{R}$ Core Team, 2015). Individual density distributions were generated for fish released at each of the 
Tisdale, Fremont Weir, and Tule canal release sites, because the proximity of each release site to the I80 detection array (range 12.5-77.7 km) might potentially influence the horizontal distribution of fish in the bypass.

Additionally, we investigated whether evidence existed for differences in survival in the Yolo Bypass as a function of east-to-west spatial location. For this analysis, a Cormack-Jolly-Seber (CJS) mark-recapture model was fit to the data (Cormack, 1964; Jolly, 1965; Seber, 1965) to estimate survival within the Yolo Bypass from the I-80 bridge downstream to the detection station at Cache Slough. Each fish's cross-stream position at the I-80 bridge was used as an individual covariate on survival to quantify the magnitude of an east-west gradient in survival.

\section{California WaterFix North Delta Diversion Intake Study}

To provide baseline information against which future effects of the intakes on juvenile salmon survival can be measured, survival probabilities were estimated for three Sacramento River reaches containing the proposed sites of the three new North Delta Diversion intake structures. The three reaches were 3.23, 4.12, and 5.37-km-long, respectively (fig. 1). Survival probabilities were estimated independently for each of the five fish releases. Of the 1,197 tagged fish released for this study, only fish that were detected at the array in the Sacramento River below the mouth of the Feather River were included as part of the analysis.

A CJS mark-recapture model was used to estimate the reach survival and detection probability parameters for the three reaches (Cormack, 1964; Jolly, 1965; Seber, 1965). Additionally, cumulative and standardized reach survival probabilities were calculated as derived model parameters. The cumulative survival probability for the combined total reach length $(12.72 \mathrm{~km})$ was calculated as the product of the three individual reach survival parameters. As with the multistate model, model parameters were estimated using HMC within the Stan probabilistic modeling language. Prior distributions for the model parameters were assumed to be uniform between 0 and 1. A total of 40,000 simulated post-warm up samples were obtained from the Bayesian posterior distribution using four independent Markov chain Monte Carlo chains. From these samples the median (50th percentile) survival and detection probabilities, and the 95-percent credible intervals ( 2.5 to 97.5 percentile) were determined.

\section{Results}

\section{Survival, Routing, and Travel Time}

\section{Survival Estimates}

Overall survival through the Delta from Fremont Weir to Chipps Island varied by route, with estimates ranging from 0.142 to 0.843 (table 2; fig. 4). Survival was generally highest for fish remaining in the mainstem Sacramento, with release specific survival estimates ranging from 0.552 to 0.843 , and with survival for three of the five release groups above 0.7. Survival among routes was lowest for fish migrating through the Interior Delta via Georgiana Slough; release specific survival estimates for this route ranged from 0.142 to 0.695 , with survival for three of the five release groups lower than 0.6. Survival estimates for all routes except for the Yolo Bypass varied by release group in a similar manner: later release groups, coincident with greater flow and overtopping of the Fremont Weir, displayed higher survival estimates than did earlier release groups. For the three release groups where survival from the Fremont Weir to Chipps Island through the Yolo Bypass was estimable, those estimates were quite consistent, ranging from 0.659 to 0.689 . 
Table 2. Derived parameters for route-specific overall survival from the Fremont Weir to Chipps Island, Sacramento-San Joaquin River Delta, California.

[Lower and Upper credible limit: Denotes the 5th and 95th percentiles of the posterior distributions for each parameter, respectively]

\begin{tabular}{|c|c|c|c|c|c|}
\hline Name & Release & Median & $\begin{array}{l}\text { Lower } \\
\text { credible } \\
\text { limit }\end{array}$ & $\begin{array}{c}\text { Upper } \\
\text { credible } \\
\text { limit }\end{array}$ & Route description \\
\hline & \multicolumn{5}{|c|}{ Survival parameters } \\
\hline \multirow{5}{*}{$S_{\mathrm{SAC}}$} & 1 & 0.552 & 0.458 & 0.644 & Sacramento River \\
\hline & 2 & 0.685 & 0.549 & 0.832 & \\
\hline & 3 & 0.704 & 0.549 & 0.867 & \\
\hline & 4 & 0.748 & 0.634 & 0.860 & \\
\hline & 5 & 0.843 & 0.738 & 0.925 & \\
\hline \multirow[t]{3}{*}{$S_{\text {YOLO }}$} & 3 & 0.689 & 0.558 & 0.820 & Yolo Bypass to Cache \\
\hline & 4 & 0.677 & 0.597 & 0.767 & Slough \\
\hline & 5 & 0.659 & 0.574 & 0.745 & \\
\hline \multirow[t]{5}{*}{$S_{\mathrm{SUT} / \mathrm{STM}}$} & 1 & 0.369 & 0.276 & 0.473 & Sutter Slough or Steamboat \\
\hline & 2 & 0.654 & 0.524 & 0.781 & Slough \\
\hline & 3 & 0.614 & 0.467 & 0.761 & \\
\hline & 4 & 0.697 & 0.531 & 0.827 & \\
\hline & 5 & 0.716 & 0.580 & 0.836 & \\
\hline \multirow[t]{5}{*}{$S_{\mathrm{GEO}}$} & 1 & 0.142 & 0.068 & 0.256 & Georgiana Slough to \\
\hline & 2 & 0.385 & 0.252 & 0.548 & Interior Delta \\
\hline & 3 & 0.564 & 0.390 & 0.760 & \\
\hline & 4 & 0.695 & 0.526 & 0.838 & \\
\hline & 5 & 0.613 & 0.466 & 0.760 & \\
\hline \multirow{5}{*}{$S_{\mathrm{NON}-\mathrm{YOLO}}$} & 1 & 0.352 & 0.291 & 0.419 & All routes combined except \\
\hline & 2 & 0.507 & 0.413 & 0.616 & Yolo Bypass \\
\hline & 3 & 0.600 & 0.490 & 0.713 & \\
\hline & 4 & 0.665 & 0.564 & 0.762 & \\
\hline & 5 & 0.735 & 0.652 & 0.811 & \\
\hline
\end{tabular}




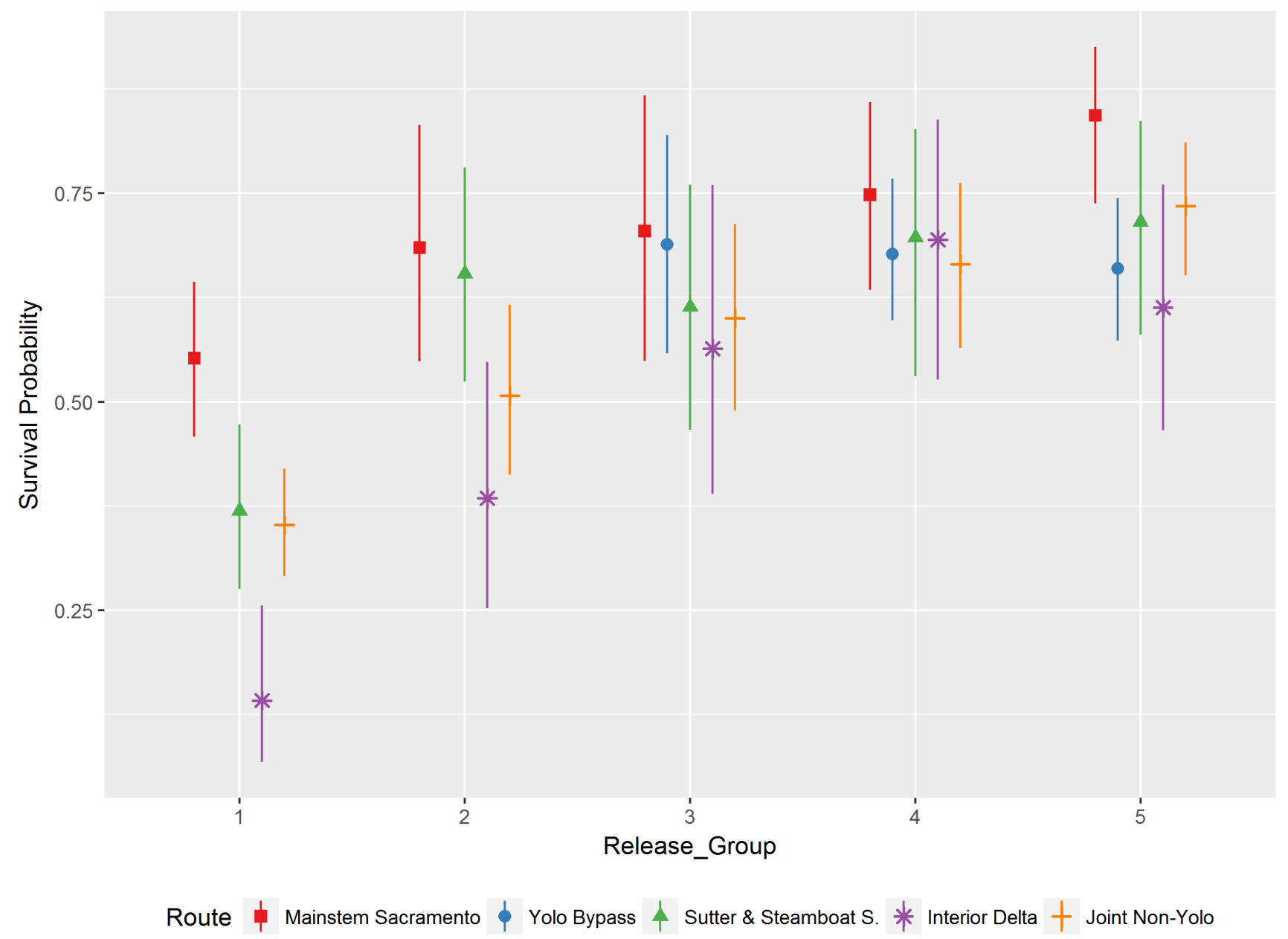

Figure 4. Median probability of survival with upper and lower credible limits (the 5th and 95th percentiles of the posterior distributions for each parameter, respectively) from Fremont Weir to Chipps Island by route through the North Delta, California.

Parameter estimates of survival within individual reaches ranged from 0.375 to 0.992 (appendix 1; table 1). Among reaches, survival was generally highest in upstream, riverine reaches, including the Sacramento River above the entrance to Georgiana Slough (reaches A2, A3, A4, and A5), the upper Yolo Bypass from Fremont Weir to the I-80 bridge (reach B1), and Steamboat Slough (reaches C41B and C42B). Survival was generally lowest in tidal reaches such as the Interior Delta from the junction of Georgiana Slough with the Lower Mokelumne River to Chipps Island (reach D6), and from the junction of Cache Slough with the Sacramento River to Chipps Island (reach C6). Among releases, reach-specific survival estimates displayed similar trends to those noted for route-specific survival, with Release Groups 1 and 2 coinciding with lower flows before overtopping of the Fremont Weir associated with lower survival than in Release Groups 3, 4, and 5 when flows were higher. 


\section{Migration Routing Estimates}

We estimated the proportion of juvenile salmon migrating from the Fremont Weir to Chipps Island via each of the four main routes. Median estimates of the proportion migrating via the Sacramento River varied by release group and ranged from 0.115 to 0.501 (table 3 ). For Release Groups 3 through 5, estimates of the proportion migrating through the Yolo Bypass ranged from 0.012 to 0.801. Migration proportions through Sutter and Steamboat Sloughs and Georgiana Slough to the Interior Delta were generally lower, with estimates for the proportion migrating via Sutter and Steamboat Sloughs ranging from 0.050 to 0.361, and via Georgiana Slough and the Interior Delta ranging from 0.031 to 0.233 (table 3 ).

Table 3. Derived parameters for route-specific entrainment probabilities from the Fremont Weir to Chipps Island, Sacramento-San Joaquin River Delta, California.

[Lower and Upper credible limit: Denote the 5th and 95th percentiles of the posterior distributions for each parameter, respectively]

\begin{tabular}{|c|c|c|c|c|c|}
\hline Name & Release & Median & $\begin{array}{c}\text { Lower } \\
\text { credible } \\
\text { limit }\end{array}$ & $\begin{array}{l}\text { Upper credible } \\
\text { limit }\end{array}$ & Route description \\
\hline & \multicolumn{5}{|c|}{ Routing parameters } \\
\hline \multirow[t]{5}{*}{$\Psi_{\mathrm{SAC}}$} & 1 & 0.501 & 0.434 & 0.567 & Sacramento River \\
\hline & 2 & 0.447 & 0.389 & 0.505 & \\
\hline & 3 & 0.389 & 0.321 & 0.461 & \\
\hline & 4 & 0.115 & 0.061 & 0.187 & \\
\hline & 5 & 0.458 & 0.371 & 0.543 & \\
\hline \multirow[t]{5}{*}{$\Psi_{\text {YOLO }}$} & 1 & 0.000 & 0.000 & 0.000 & Yolo Bypass to Cache \\
\hline & 2 & 0.000 & 0.000 & 0.000 & Slough \\
\hline & 3 & 0.012 & 0.003 & 0.035 & \\
\hline & 4 & 0.801 & 0.687 & 0.890 & \\
\hline & 5 & 0.040 & 0.008 & 0.113 & \\
\hline \multirow[t]{5}{*}{$\Psi_{\text {SUT/STM }}$} & 1 & 0.311 & 0.252 & 0.375 & Sutter Slough or Steamboat \\
\hline & 2 & 0.360 & 0.303 & 0.420 & Slough \\
\hline & 3 & 0.361 & 0.292 & 0.435 & \\
\hline & 4 & 0.050 & 0.025 & 0.093 & \\
\hline & 5 & 0.294 & 0.216 & 0.381 & \\
\hline \multirow[t]{5}{*}{$\Psi_{\mathrm{GEO}}$} & 1 & 0.186 & 0.137 & 0.242 & Georgiana Slough to \\
\hline & 2 & 0.191 & 0.148 & 0.239 & Interior Delta \\
\hline & 3 & 0.233 & 0.175 & 0.297 & \\
\hline & 4 & 0.031 & 0.015 & 0.054 & \\
\hline & 5 & 0.198 & 0.147 & 0.254 & \\
\hline \multirow[t]{6}{*}{$\Psi_{\text {NON-YOLO }}$} & 1 & 1.000 & 1.000 & 1.000 & All routes combined except \\
\hline & 2 & 1.000 & 1.000 & 1.000 & \\
\hline & & & & & Yolo Bypass \\
\hline & 3 & 0.988 & 0.965 & 0.997 & \\
\hline & 4 & 0.199 & 0.110 & 0.313 & \\
\hline & 5 & 0.960 & 0.887 & 0.992 & \\
\hline
\end{tabular}


Route migration proportions for Release Group 4, when both flows and the river stage at Fremont Weir were highest, contrasted greatly with migration proportions for the other four release groups. Median entrainment probability into the Yolo Bypass for Release Group 4 was estimated to be greater than 80 percent. This proportion coincides with the lowest estimates of migration proportion for each of the other routes and was the only release group of the three where fish had an opportunity to migrate through the Yolo Bypass where more than 5 percent of fish were estimated to have done so. For each of the other release groups, when few fish were estimated to have migrated through the Yolo Bypass, migration proportions through each of the other three routes was quite stable (fig. 5).

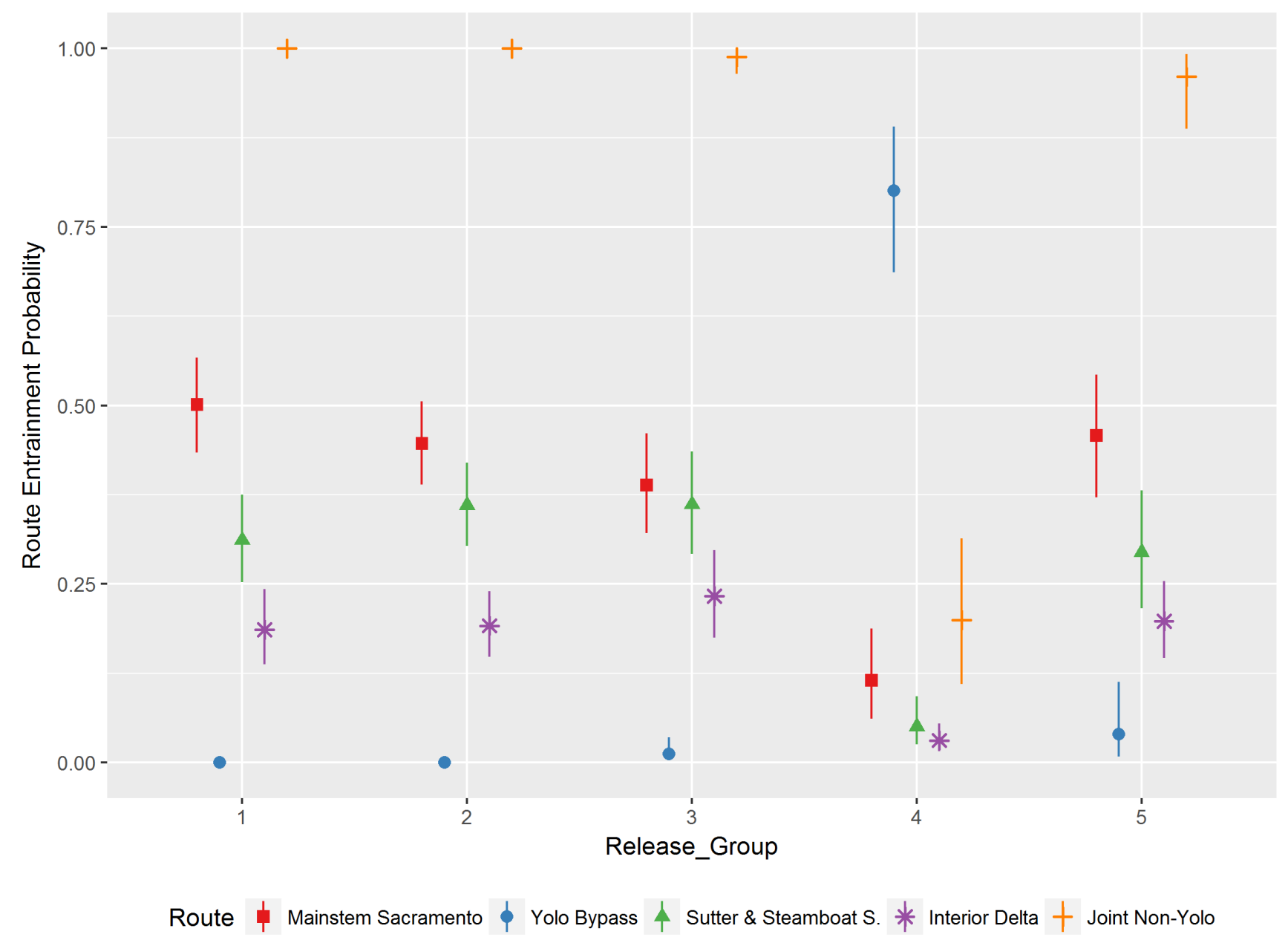

Figure 5. Median probability of entrainment with upper and lower credible limits (the 5th and 95th percentiles of the posterior distributions for each parameter, respectively) from Fremont Weir to Chipps Island, California, by route. 


\section{Travel Time Parameter Estimates}

Mean travel time estimates varied by route through the Delta and by release group, with estimated mean travel time from the Fremont Weir to Chipps Island ranging from 2.70 days to 8.06 days (fig. 6). Travel time for non-Yolo Bypass routes was shorter during Release Groups 3, 4, and 5, when flows were higher and the Fremont Weir was overtopping, than for Release Groups 1 and 2 (table 4; fig. 6). For fish migrating via the Yolo Bypass, travel time did not vary substantially with release group. For all release groups, fish migrating via either the mainstem Sacramento River (mean travel time range 2.70-6.74 days) or Sutter and Steamboat Sloughs (range 2.71-7.04 days) arrived at Chipps Island faster than fish migrating via the Yolo Bypass (predicted mean travel time range 4.195.08 days for Release Groups 3-5). Fish migrating via the Interior Delta exhibited the longest estimated mean travel times (range 5.41-8.06 days).

Table 4. Derived parameters for route-specific travel times from the Fremont Weir to Chipps Island, SacramentoSan Joaquin River Delta, California.

[Lower and Upper credible limit: Denote the 5th and 95th percentiles of the posterior distributions for each parameter, respectively]

\begin{tabular}{llllll}
\hline Name & Release & Median & $\begin{array}{c}\text { Lower } \\
\text { credible } \\
\text { limit }\end{array}$ & $\begin{array}{c}\text { Upper } \\
\text { credible } \\
\text { limit }\end{array}$ & Route description \\
\hline & & & Predicted mean travel time & \\
\hline $\bar{\tau}_{\text {SAC }}$ & 1 & 6.743 & 6.404 & 7.090 & Sacramento River \\
& 2 & 3.669 & 3.480 & 3.859 & \\
& 3 & 3.163 & 2.936 & 3.393 & \\
& 4 & 2.696 & 2.457 & 2.942 & Yolo Bypass to Cache \\
& 5 & 2.945 & 2.732 & 3.169 & Slough \\
$\bar{\tau}_{\text {YOLO }}$ & 3 & 4.186 & 4.001 & 4.381 & Sutter Slough or Steamboat \\
& 4 & 5.084 & 4.827 & 5.361 & Slough \\
& 5 & 4.531 & 4.294 & 4.785 & \\
$\bar{\tau}_{\text {SUT/STM }}$ & 1 & 7.040 & 6.374 & 8.009 & Georgiana Slough to \\
& 2 & 4.308 & 3.936 & 4.891 & \\
& 3 & 2.885 & 2.659 & 3.127 & \\
& 4 & 2.792 & 2.376 & 3.443 & \\
$\bar{\tau}_{\text {GEO }}$ & 5 & 2.712 & 2.465 & 2.983 & \\
& 1 & 8.055 & 6.993 & 9.239 & \\
& 2 & 7.512 & 6.888 & 8.134 & \\
& 3 & 5.608 & 5.158 & 6.073 & \\
& 4 & 6.401 & 5.694 & 7.148 & \\
\hline
\end{tabular}




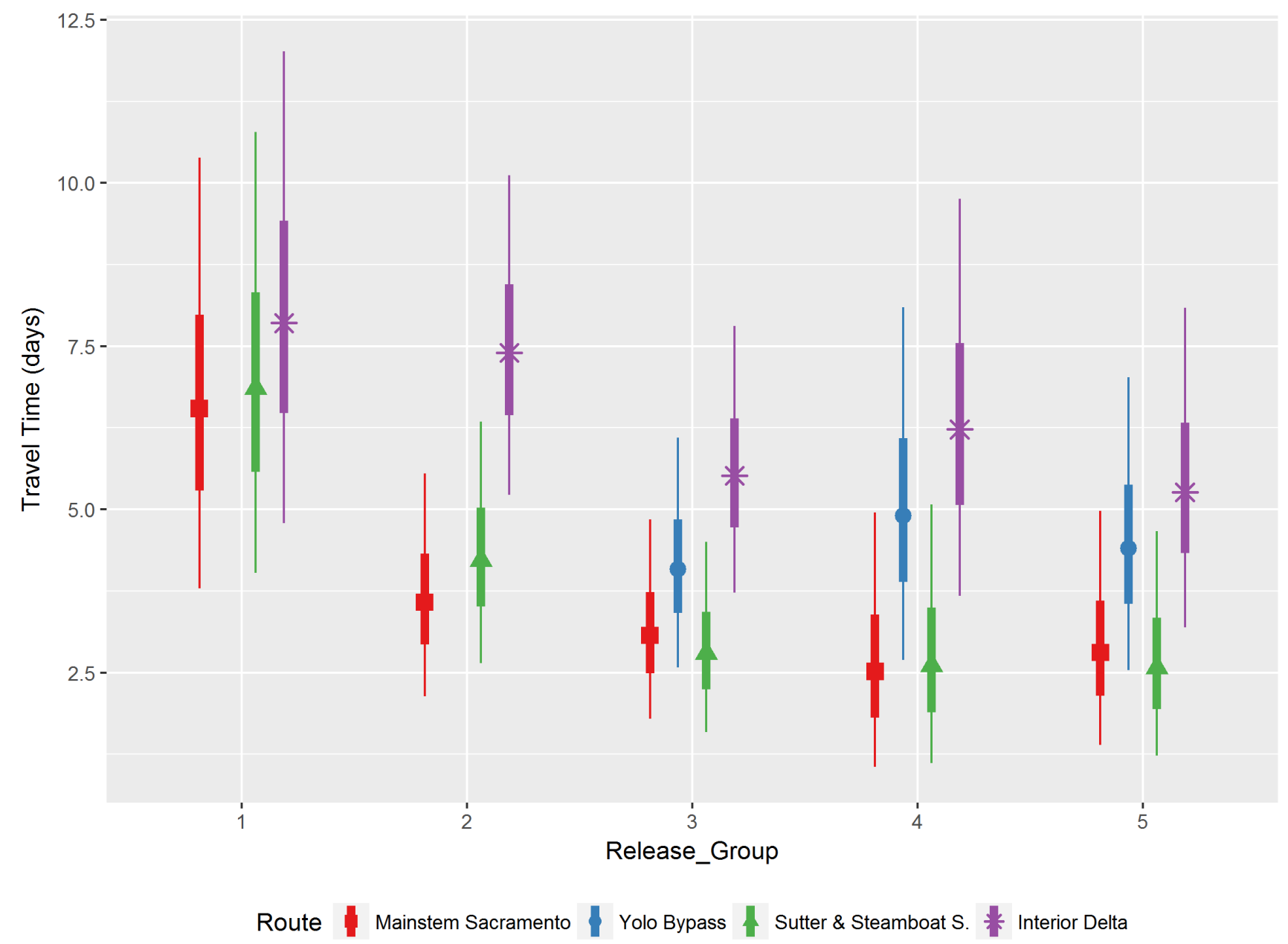

Figure 6. Route-specific travel time quantiles from Fremont Weir to Chipps Island, Sacramento-San Joaquin River Delta, California. (Dots indicate medians, thick lines show 25th-75th percentiles, and ends of thin lines show 5 th and 95 th percentiles. Travel time quantiles are derived from a gamma $(\alpha, \beta)$ distribution where $\alpha, \beta$ are the median posterior values.) 


\section{Mean Daily Survival Probabilities}

Derived per day survival estimates as calculated according to the definitions given in the Derived Parameters subsection of the Methods above were generally consistent across both route and release group. Mean daily survival estimates ranged from 0.785 to 0.945 (table 5). Daily survival was lowest for the earlier release groups in the Sutter and Steamboat Slough and Interior Delta routes, when flows were lower. Daily survival in the Yolo Bypass route was similar to that in the mainstem Sacramento River for Release Groups 3 through 5, when the Fremont Weir was overtopping, and was not substantially different from combined weighted daily survival through non-Yolo routes.

Table 5. Derived parameters for route-specific daily survival from the Fremont Weir to Chipps Island, Sacramento-San Joaquin River Delta, California.

[Lower and Upper credible limit: Denote the 5th and 95th percentiles of the posterior distributions for each parameter, respectively]

\begin{tabular}{|c|c|c|c|c|c|}
\hline Name & Release & Median & $\begin{array}{l}\text { Lower } \\
\text { credible } \\
\text { limit }\end{array}$ & $\begin{array}{l}\text { Upper } \\
\text { credible } \\
\text { limit }\end{array}$ & Route description \\
\hline & \multicolumn{5}{|c|}{ Daily survival parameters } \\
\hline \multirow[t]{5}{*}{$S / D_{\mathrm{SAC}}$} & 1 & 0.916 & 0.890 & 0.937 & Sacramento River \\
\hline & 2 & 0.901 & 0.848 & 0.952 & \\
\hline & 3 & 0.895 & 0.826 & 0.956 & \\
\hline & 4 & 0.898 & 0.843 & 0.946 & \\
\hline & 5 & 0.944 & 0.902 & 0.974 & \\
\hline \multirow[t]{3}{*}{$S / D_{\text {YOLO }}$} & 3 & 0.915 & 0.870 & 0.953 & Yolo Bypass to Cache \\
\hline & 4 & 0.926 & 0.903 & 0.949 & Slough \\
\hline & 5 & 0.912 & 0.883 & 0.937 & \\
\hline \multirow[t]{5}{*}{$S / D_{\text {SUT } / \text { STM }}$} & 1 & 0.869 & 0.832 & 0.900 & Sutter Slough or Steamboat \\
\hline & 2 & 0.907 & 0.859 & 0.944 & Slough \\
\hline & 3 & 0.844 & 0.768 & 0.910 & \\
\hline & 4 & 0.880 & 0.794 & 0.935 & \\
\hline & 5 & 0.884 & 0.815 & 0.937 & \\
\hline \multirow{5}{*}{$S / D_{\mathrm{GEO}}$} & 1 & 0.785 & 0.711 & 0.847 & Georgiana Slough to \\
\hline & 2 & 0.881 & 0.831 & 0.923 & Interior Delta \\
\hline & 3 & 0.903 & 0.844 & 0.952 & \\
\hline & 4 & 0.945 & 0.904 & 0.973 & \\
\hline & 5 & 0.914 & 0.866 & 0.951 & \\
\hline \multirow[t]{5}{*}{$S / D_{\mathrm{NON}-\mathrm{YO}}$} & 1 & 0.885 & 0.862 & 0.905 & All routes combined except \\
\hline & 2 & 0.901 & 0.865 & 0.934 & Yolo Bypass \\
\hline & 3 & 0.884 & 0.836 & 0.927 & \\
\hline & 4 & 0.907 & 0.873 & 0.938 & \\
\hline & 5 & 0.920 & 0.891 & 0.945 & \\
\hline
\end{tabular}




\section{Spatial Distribution and Survival within the Yolo Bypass}

The horizontal distribution of tagged fish from east to west in Yolo Bypass parallel to I-80 tended to be increasingly skewed towards the east bank the closer the fish's release site was to I-80 (fig. 7). This likely reflects not only the proximity of a particular release site to the I- 80 detection array, but also the point where the fish were released, particularly those fish released within the bypass, as both the Fremont Weir and Tule Canal releases occurred within the bypass near the east bank. The horizontal density of fish released closest to the I-80 array at the Tule Canal was greatly skewed towards the east bank. The densities of these fish dropped off rapidly with distance from the east bank out to about $370 \mathrm{~m}$ and remained low to a maximum distance of about 2,000 $\mathrm{m}$. Fish released in the bypass below the Fremont Weir also had a horizontal distribution skewed towards the east bank of the bypass, but it was much less pronounced and densities were only about a third of those of the Tule Canal fish near the east bank. Fish densities for this group peaked about $140 \mathrm{~m}$ from the east end of the array, decreased slowly to about $670 \mathrm{~m}$ and remained steady out to about $1,280 \mathrm{~m}$, and then declined again down to the lowest densities between 2,000 and 2,500 m from the east bank.

In contrast to within-Yolo release groups, the fish that were released in the Sacramento River upstream of Fremont Weir and that entered the bypass volitionally were nearly equally dispersed from 0 to about 2,000 $\mathrm{m}$ from the east bank before densities gradually decreased out to 2,500 $\mathrm{m}$ (fig. 7). No fish were first detected on the western group of four receivers located 4,231 to 4,812 m from the east bank; however, it is important to note that since the Yolo Bypass is a seasonally inundated floodplain and not a well-defined river channel, this far western extent of the Bypass may not have been flooded for parts of the study duration.

Median survival for all tagged fish detected at the I-80 array to Cache Slough was estimated at 0.839 ( 5 and 95 percent credible limits 0.784 and 0.887 , respectively). Survival did not vary significantly with location of first detection within the I-80 array, and no effect of distance of first detection from the east bank on survival was observed. For example, survival from I-80 to Cache Slough for a fish first detected at the easternmost receiver of the I- 80 array was estimated at 0.847 $(0.784,0.901$ credible interval), while fish first detected at the westernmost receiver had an estimated survival of $0.819(0.690,0.919$ credible interval). 


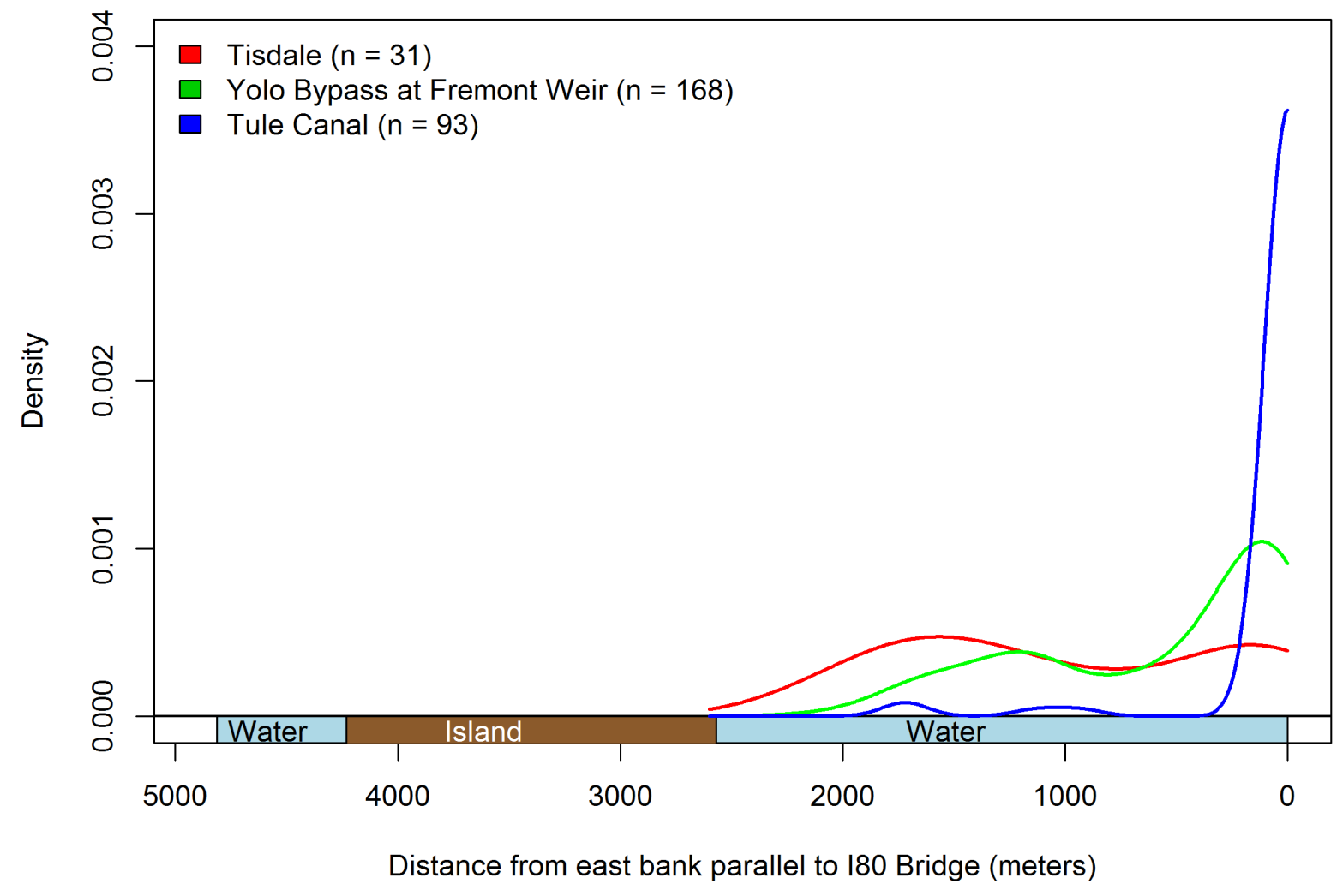

Figure 7. Cross-stream distribution of tagged fish distribution within Yolo Bypass at the I-80 bridge, separated by release site, California. 


\section{California WaterFix North Delta Diversion Intake Study}

The number of fish used to estimate juvenile Chinook salmon survival within the three contiguous Sacramento River reaches encompassing proposed North Delta Diversion intake sites ranged from 81 to 240 among the five fish releases (table 6).

Table 6. Number of juvenile Chinook salmon used to estimate survival for three Sacramento River reaches encompassing proposed North Delta Diversion intakes in the North Delta, Sacramento-San Joaquin River Delta, California.

\begin{tabular}{lrrrrrr}
\hline \multicolumn{7}{c}{ Number of fish by release } \\
\hline \multicolumn{1}{c}{ Release site } & \multicolumn{1}{c}{$\mathbf{2}$} & $\mathbf{3}$ & $\mathbf{4}$ & $\mathbf{5}$ & Total \\
\hline Tisdale & 240 & 240 & 81 & 5 & 28 & 594 \\
Verona & 0 & 0 & 0 & 100 & 99 & 199 \\
Total & 240 & 240 & 81 & 105 & 127 & 793 \\
\hline
\end{tabular}

Median absolute reach survival probabilities for the three Sacramento River reaches encompassing the three proposed North Delta Diversion intake sites were generally high among all five fish releases (range 0.975-0.995; table 7). Differences in median survival among releases within a reach were 0.020 or less (range 0.013-0.02). Median cumulative survival probabilities for the combined 12.72 kilometer reach generally ranged between 0.921 and 0.942 , except for the second fish release where the median cumulative survival was 0.974 (table 7). Median survival probabilities were consistently higher for the second release than for the other releases for all three reaches (range 0.9900.995). Differences in median reach survivals within releases were within the range of parameter uncertainty indicated by the 95 percent credible intervals for each parameter.

Table 7. Median reach-specific and cumulative survival estimates, and 95-percent credible intervals by fish release and reach for the three proposed water-intake sites, Sacramento-San Joaquin River Delta, California.

\begin{tabular}{lcccc}
\hline \multicolumn{5}{c}{ Absolute reach survival } \\
\hline \multicolumn{1}{c}{ Release } & \multicolumn{1}{c}{ Reach 1 } & Reach 2 & Reach 3 & Cumulative survival \\
\hline 1 & $0.984(0.957-0.996)$ & $0.984(0.956-0.997)$ & $0.977(0.946-0.993)$ & $0.942(0.900-0.971)$ \\
2 & $0.994(0.967-1.000)$ & $0.990(0.962-0.999)$ & $0.995(0.975-1.000)$ & $0.974(0.937-0.993)$ \\
3 & $0.980(0.916-0.999)$ & $0.981(0.917-0.999)$ & $0.984(0.924-0.999)$ & $0.932(0.855-0.981)$ \\
4 & $0.976(0.903-0.999)$ & $0.977(0.907-0.999)$ & $0.983(0.922-0.999)$ & $0.921(0.844-0.977)$ \\
5 & $0.987(0.945-1.000)$ & $0.988(0.945-1.000)$ & $0.975(0.921-0.999)$ & $0.942(0.882-0.982)$ \\
Mean & 0.984 & 0.984 & 0.983 & 0.942 \\
\hline
\end{tabular}




\section{Discussion}

In release groups where survival in the Yolo Bypass was estimable, overall survival from the Fremont Weir to Chipps Island was similar between fish travelling through the Yolo Bypass and fish travelling non-Yolo routes (fig. 4). Upon closer inspection, however, interesting patterns in survival emerge. Survival of migrating juvenile Chinook through the North Delta has been found to exhibit a positive relationship with flow in routes other than the Yolo Bypass (Kjelson and others, 1982; Kjelson and Brandes, 1989; Newman and Rice, 2002; Newman, 2003; Perry and others, in press). Although we did not conduct an analysis that relates survival directly to flow covariates, figure 4 shows that in nonYolo routes, survival increased with each successive release, coincident with an increase in flow among releases (fig. 2).

The pattern of higher survival coincident with higher flows seen in non-Yolo Bypass routes was not apparent in the Yolo Bypass route survival estimates, which were remarkably consistent across the three release groups for which estimates are available (fig. 4). This consistency holds even for Release Group 3, during which the Fremont Weir had not quite overtopped, and for which tagged fish were released directly into the Yolo Bypass. Examination of detection times at Cache Slough reveals that a large majority of these fish exited the Yolo Bypass 1-3 days after initial overtopping of the Fremont Weir. Thus, there is a strong possibility that while flows on release in the Yolo Bypass were quite low for this group, subsequent overtopping of the Fremont Weir could have led to increased flows, shorter travel times, and high survival (fig. 2).

While differences in survival between Yolo and non-Yolo routes were small at the high flows seen during this study, at lower flows, survival through non-Yolo Bypass routes has been shown to decrease. Survival was lower through these routes for Release Groups 1 and 2 when no fish migrated through the Yolo Bypass (fig. 4). If survival through the Yolo Bypass is indeed largely independent of flows in the Bypass, it seems possible that overall salmon survival could benefit by diverting fish into the Yolo Bypass when flows through the North Delta are lower, provided flows in Yolo were at least as high as during Release Group 3. A strategically placed notch in the Fremont Weir could achieve just such a purpose.

Estimates of the proportion of fish passing the Fremont Weir into the Yolo Bypass are only meaningful for Release Groups 4 and 5. While the estimate for Release Group 3 is above 0 , this release was conducted just before the Fremont Weir overtopped, and most tagged fish likely passed the weir before it was overtopped (fig. 2). Entrainment into Yolo Bypass differed greatly between the last two release groups, however. Over 80 percent of fish were estimated to have migrated through Yolo Bypass during Release Group 4 (fig. 5), when flow into Yolo Bypass at the Fremont Weir was at its peak. This estimate seems to indicate that when enough water goes into the Yolo Bypass, most fish will migrate via this route. However, less than 5 percent of fish migrated through the Yolo Bypass during Release Group 5. This release was conducted only 2 days later, while Yolo Bypass flow at Fremont Weir was declining but still substantial. Analysis of near-field acoustic-tagged fish tracks conducted for this study indicate that as discharge over the Fremont Weir increases, mean crosssectional fish position moved closer to the weir (Blake and others, 2017). In contrast, as flows near Fremont Weir decrease, but are still great enough to provide substantial flow into the Yolo Bypass, mean fish position moves away from the bank formed by the weir and toward the Sacramento River centerline. Thus, it seems reasonable to posit that at certain overtopping flow levels, fish are not close enough to the Fremont Weir to become entrained over the weir and into the Yolo Bypass, even though a substantial fraction of river flow is entering the Bypass. These results suggest that any proposed notch in the Fremont Weir should be carefully designed to have the desired effect of diverting both water and fish into the Yolo Bypass. Additionally, we remind the reader that these results are from a study involving only actively migrating juvenile Chinook salmon smolts, and that salmon in different 
life stages will likely behave differently. For example, the Yolo Bypass has been viewed as potential rearing habitat for juvenile salmon. Actively migrating smolts are not likely to see a benefit from increased rearing habitat, but salmon fry very well may benefit. We encourage further research on the applied potential benefits of access to the Yolo Bypass for various life stages.

\section{Acknowledgments}

We would like to thank the USGS California Water Science Center for their efforts in coordinating this study, as well as for technical assistance. Additionally, the U.S. Army Corps of Engineers and University of California Davis assisted in providing and deploying acoustic hydrophones and receivers used for the study. Funding for this study was provided by the California Department of Water Resources under interagency agreement 4600009512.

\section{References Cited}

Blake, A.R., Stumpner, P., and Burau, J.R., 2017, A simulation method for combining hydrodynamic data and acoustic tag tracks to predict the entrainment of juvenile salmonids onto the Yolo Bypass under future engineering scenarios: Delta Stewardship Council, State of California, http://deltacouncil.ca.gov/docs/simulation-method-combining-hydrodynamic-data-and-acoustic-tagtracks-predict-entrainment.

Brandes, P.L., and McLain, J.S., 2001, Juvenile Chinook salmon abundance, distribution, and survival in the Sacramento-San Joaquin Estuary-Contributions to the Biology of the Central Valley Salmonids: Fish Bulletin 179, v. 2, p. 39-138.

California Department of Water Resources, 2016, Experimental design and study plan for the 2014 Georgiana Slough Floating Fish Guidance Structure Performance Evaluation: Sacramento, California, AECOM.

Carpenter, B., Gelman, A., Hoffman, M.D., Lee, D., Goodrich, B., Betancourt, M., Brubaker, M., Guo, J., Li, P., and Riddell, A., 2017, Stan-A probabilistic programming language: Journal of Statistical Software, v. 76, no. 1, 32 p.

Cormack, R.M., 1964, Estimates of survival from the sighting of marked animals: Biometrika, v. 51, no. 3-4, p. 429-438, https://doi.org/10.1093/biomet/51.3-4.429.

Gibson, A.J.F., Halfyard, E.A., Bradford, R.G., Stokesbury, M.J.W., and Redden, A.M., 2015, Effects of predation on telemetry-based survival estimates - Insights from a study on endangered Atlantic salmon juvenile Chinook salmons: Canadian Journal of Fisheries and Aquatic Sciences, v. 72, p. 113, https://doi.org/10.1139/cjfas-2014-0245.

I.C.F. International, 2016, Biological assessment for the California WaterFix: Prepared for Bureau of Reclamation, http://cms.capitoltechsolutions.com/ClientData/CaliforniaWaterFix/uploads/FIX_BA_TOC_Rev1.pd f.

Jolly, G.M., 1965, Explicit estimates from capture-recapture data with both death and immigrationstochastic model: Biometrika, v. 52, no. 1-2, p. 225-247, https://doi.org/10.1093/biomet/52.1-2.225.

Lebreton, J.D., Nichols, J.D., Barker, R.J., Pradel, R., and Spendelow, J.A., 2009, Modeling individual animal histories with multistate capture-recapture models: Advances in Ecological Research, v. 41. Academic Press, p. 87-173, https://doi.org/10.1016/S0065-2504(09)00403-6.

Liedtke, T.L., and Hurst, W.R., 2017, Yolo Bypass juvenile salmon utilization study 2016-Summary of acoustically tagged juvenile salmon and study fish release, Sacramento River, California: U.S. Geological Survey Data Series 1066, 49 p. [Also available at https://doi.org/10.3133/ds1066.] 
Kjelson, M.A., Raquel, P.F., and Fisher, F.W., 1982, Life history of fall-run juvenile Chinook salmon, Oncorhynchus tshawytscha, in the Sacramento-San Joaquin Estuary, California, in Kennedy, V.S., ed., Estuarine comparisons: New York, Academic Press, p. 393-411, https://doi.org/10.1016/B9780-12-404070-0.50029-6.

Kjelson, M.A., and Brandes, P.L., 1989, The use of smolt survival estimates to quantify the effects of habitat changes on salmonid stocks in the Sacramento-San Joaquin rivers, California: Canadian Special Publication of Fisheries and Aquatic Sciences, v. 105, p. 100-115.

Newman, K.B., 2003, Modelling paired release-recovery data in the presence of survival and capture heterogeneity with application to marked juvenile salmon: Statistical Modelling, v. 3, no. 3, p. 157177, https://doi.org/10.1191/1471082X03st055oa.

Newman, K.B., and Rice, J., 2002, Modeling the survival of Chinook salmon smolts outmigrating through the lower Sacramento River system: Journal of the American Statistical Association, v. 97, no. 460, p. 983-993, https://doi.org/10.1198/016214502388618771.

Newman, K.B., and Brandes, P.L., 2010, Hierarchical modeling of juvenile Chinook salmon survival as a function of Sacramento-San Joaquin Delta water exports: North American Journal of Fisheries Management, v. 30, no. 1, p. 157-169, https://doi.org/10.1577/M07-188.1.

Nobriga, M., Feyrer, F., Baxter, R., and Chotkowski, M., 2005, Fish community ecology in an altered river delta - Spatial patterns in species composition, life history strategies, and biomass: Estuaries, $\mathrm{v}$. 28, no. 5, p. 776-785, https://doi.org/10.1007/BF02732915.

Perry, R.W., Skalski, J.R., Brandes, P.L., Sandstrom, P.T., Klimley, A.P., Ammann, A., and MacFarlane, B., 2010, Estimating survival and migration route probabilities of juvenile Chinook salmon in the Sacramento-San Joaquin River Delta: North American Journal of Fisheries Management, v. 30, no. 1, p. 142-156, https://doi.org/10.1577/M08-200.1.

Perry, R.W., Brandes, P.L., Burau, J.R., Klimley, A.P., MacFarlane, B., Michel, C., and Skalski, J.R., 2013, Sensitivity of survival to migration routes used by juvenile Chinook salmon to negotiate the Sacramento-San Joaquin River Delta: Environmental Biology of Fishes, v. 96, no. 2-3, p. 381-392. https://doi.org/10.1007/s10641-012-9984-6.

Perry, R.W., Brandes, P.L., Burau, J.R., Sandstrom, P.T., and Skalski, J.R., 2015, Effect of tides, river flow, and gate operations on entrainment of juvenile salmon into the Interior Sacramento-San Joaquin River delta: Transactions of the American Fisheries Society, v. 144, no. 3, p. 445-455, https://doi.org/10.1080/00028487.2014.1001038.

Perry, R.W., Pope, A.C., Romine, J.G., Brandes, P.L., Burau, J.R., Blake, A.R., Ammann, A.J., and Michel, C.J., in press, Flow-mediated effects on travel time, routing, and survival of juvenile Chinook salmon in a spatially complex, tidally forced river delta: Canadian Journal of Fisheries and Aquatic Sciences.

R Core Team, 2015, R-A language and environment for statistical computing: Vienna, Austria, $\mathrm{R}$ Foundation for Statistical Computing, https:/www.R-project.org/.

Raymond, H.L., 1988, Effects of hydroelectric development and fisheries enhancement on spring and summer Chinook salmon and steelhead in the Columbia River basin: North American Journal of Fisheries Management, v. 8, no. 1, p. 1-24, https://doi.org/10.1577/1548$\underline{\text { 8675(1988)008<0001:EOHDAF }>2.3 . \mathrm{CO} ; 2 .}$

Seber, G.A.F., 1965, A note on the multiple recapture census: Biometrika, v. 52, no. 1-2, p. 249-259, https://doi.org/10.1093/biomet/52.1-2.249.

Skalski, J.R., Townsend, R., Lady, J., Giorgi, A.E., Stevenson, J.R., and McDonald, R.D., 2002, Estimating route-specific passage and survival probabilities at a hydroelectric project from smolt radiotelemetry studies: Canadian Journal of Fisheries and Aquatic Sciences, v. 59, no. 8, p. 13851393, https://doi.org/10.1139/f02-094. 
Smith, S.G., Muir, W.D., Hockersmith, E.E., Zabel, R.W., Graves, R.J., Ross, C.V., Connor, W.P., and Arnsberg, B.D., 2003, Influence of river conditions on survival and travel time of Snake River subyearling fall Chinook salmon: North American Journal of Fisheries Management, v. 23, no. 3, p. 939-961, https://doi.org/10.1577/M02-039.

Sommer, T.R., Harrell, W.C., and Swift, T.R., 2008, Extreme hydrologic banding in a large-river Floodplain, California, U.S.A: Hydrobiologia, v. 598, no. 1, p. 409-415, https://doi.org/10.1007/s10750-007-9159-1.

Sommer, T.R., Harrell, W.C., and Nobriga, M.L., 2005, Habitat use and stranding risk of juvenile Chinook salmon on a seasonal floodplain: North American Journal of Fisheries Management, v. 25 , no. 4, p. 1493-1504, https://doi.org/10.1577/M04-208.1.

Sommer, T.R., Nobriga, M.L., Harrell, W.C., Batham, W., and Kimmerer, W.J., 2001a, Floodplain rearing of juvenile chinook salmon-Evidence of enhanced growth and survival: Canadian Journal of Fisheries and Aquatic Sciences, v. 58, no. 2, p. 325-333, https://doi.org/10.1139/f00-245.

Sommer, T.R., Harrell, W.C., Nobriga, M.L., Brown, R., Moyle, P., Kimmerer, W.J., and Schemel, L., 2001b, California's Yolo Bypass-Evidence that flood control can be compatible with fisheries, wetlands, wildlife, and agriculture: Bethesda, Maryland, Fisheries, v. 26, no. 8, p. 6-16, https://doi.org/10.1577/1548-8446(2001)026<0006:CYB $>2.0 . C O ; 2$.

Turner, J.L., and Chadwick, H.K., 1972, Distribution and abundance of young-of-the-year striped bass, Morone saxatilis, in relation to river flow in the Sacramento-San Joaquin Estuary: Transactions of the American Fisheries Society, v. 101, no. 3, p. 442-452, https://doi.org/10.1577/15488659(1972)101<442:DAAOYS $>2.0 . C O ; 2$.

U.S. Bureau of Reclamation and California Department of Water Resources, 2012, Yolo Bypass salmonid habitat and fish passage implementation plan: California Department of Water Resources, http://www.water.ca.gov/environmentalservices.

Ward, J.H., Jr., 1963, Hierarchical grouping to optimize an objective function: Journal of the American Statistical Association, v. 58, no. 301, p. 236-244, https://doi.org/10.1080/01621459.1963.10500845. 


\section{Appendix 1. Fundamental Reach-Specific Parameter Estimates}

Table 1-1. Directly estimated parameters for reach-specific survival and detection probability, for junction-specific entrainment probability, and for reach-specific gamma distributed travel time parameters.

[Lower and Upper credible limit: Denotes the 5th and 95th percentiles of the posterior distributions for each parameter, respectively]

\begin{tabular}{|c|c|c|c|c|c|}
\hline Name & Release & Median & $\begin{array}{c}\text { Lower } \\
\text { credible } \\
\text { limit }\end{array}$ & $\begin{array}{c}\text { Upper } \\
\text { credible } \\
\text { limit }\end{array}$ & Location description \\
\hline & \multicolumn{5}{|c|}{ Survival parameters } \\
\hline \multirow[t]{5}{*}{$S_{\mathrm{A} 1}$} & 1 & 0.880 & 0.839 & 0.912 & \multirow[t]{5}{*}{ Tisdale to Verona } \\
\hline & 2 & 0.861 & 0.816 & 0.905 & \\
\hline & 3 & 0.939 & 0.885 & 0.983 & \\
\hline & 4 & 0.962 & 0.876 & 0.997 & \\
\hline & 5 & 0.983 & 0.930 & 0.999 & \\
\hline \multirow[t]{5}{*}{$S_{\mathrm{A} 2}$} & 1 & 0.798 & 0.750 & 0.841 & \multirow[t]{5}{*}{ Fremont Weir to Freeport } \\
\hline & 2 & 0.937 & 0.889 & 0.971 & \\
\hline & 3 & 0.982 & 0.935 & 0.999 & \\
\hline & 4 & 0.980 & 0.929 & 0.998 & \\
\hline & 5 & 0.991 & 0.963 & 0.999 & \\
\hline \multirow[t]{5}{*}{$S_{\mathrm{A} 3}$} & 1 & 0.933 & 0.895 & 0.966 & \multirow{5}{*}{$\begin{array}{l}\text { Freeport to } \\
\text { Sutter/Steamboat Slough }\end{array}$} \\
\hline & 2 & 0.992 & 0.970 & 0.999 & \\
\hline & 3 & 0.977 & 0.921 & 0.998 & \\
\hline & 4 & 0.982 & 0.936 & 0.998 & \\
\hline & 5 & 0.988 & 0.954 & 0.999 & \\
\hline \multirow[t]{5}{*}{$S_{\mathrm{A} 4}$} & 1 & 0.939 & 0.891 & 0.975 & \multirow{5}{*}{$\begin{array}{l}\text { Sutter/Steamboat Slough to } \\
\text { Georgiana Slough }\end{array}$} \\
\hline & 2 & 0.962 & 0.924 & 0.988 & \\
\hline & 3 & 0.976 & 0.928 & 0.997 & \\
\hline & 4 & 0.969 & 0.898 & 0.998 & \\
\hline & 5 & 0.981 & 0.930 & 0.999 & \\
\hline \multirow[t]{5}{*}{$S_{\mathrm{A} 5}$} & 1 & 0.904 & 0.840 & 0.949 & \multirow{5}{*}{$\begin{array}{l}\text { Georgiana Slough to above } \\
\text { Rio Vista }\end{array}$} \\
\hline & 2 & 0.976 & 0.932 & 0.996 & \\
\hline & 3 & 0.975 & 0.905 & 0.998 & \\
\hline & 4 & 0.960 & 0.875 & 0.996 & \\
\hline & 5 & 0.976 & 0.910 & 0.998 & \\
\hline \multirow[t]{5}{*}{$S_{\mathrm{A} 6}$} & 1 & 0.886 & 0.757 & 0.986 & \multirow{5}{*}{$\begin{array}{l}\text { Above Rio Vista to Chipps } \\
\text { Island }\end{array}$} \\
\hline & 2 & 0.793 & 0.644 & 0.953 & \\
\hline & 3 & 0.793 & 0.628 & 0.965 & \\
\hline & 4 & 0.863 & 0.750 & 0.965 & \\
\hline & 5 & 0.920 & 0.822 & 0.989 & \\
\hline \multirow[t]{3}{*}{$S_{\mathrm{B} 1}$} & 3 & 0.980 & 0.946 & 0.997 & \multirow{3}{*}{$\begin{array}{l}\text { Fremont Weir to I- } 80 \\
\text { Bridge }\end{array}$} \\
\hline & 4 & 0.910 & 0.862 & 0.947 & \\
\hline & 5 & 0.933 & 0.875 & 0.981 & \\
\hline \multirow[t]{3}{*}{$S_{\mathrm{B} 3}$} & 3 & 0.851 & 0.784 & 0.905 & \multirow{3}{*}{ I-80 Bridge to Cache Slough } \\
\hline & 4 & 0.878 & 0.821 & 0.922 & \\
\hline & 5 & 0.773 & 0.692 & 0.844 & \\
\hline \multirow[t]{5}{*}{$S_{\mathrm{C} 41 \mathrm{~A}}$} & 1 & 0.797 & 0.587 & 0.973 & \multirow{5}{*}{$\begin{array}{l}\text { Sutter Slough to Miner } \\
\text { Slough }\end{array}$} \\
\hline & 2 & 0.967 & 0.878 & 0.997 & \\
\hline & 3 & 0.658 & 0.074 & 0.979 & \\
\hline & 4 & 0.795 & 0.328 & 0.983 & \\
\hline & 5 & 0.898 & 0.131 & 0.994 & \\
\hline \multirow[t]{3}{*}{$S_{\mathrm{C} 42 \mathrm{~A}}$} & 1 & 0.781 & 0.513 & 0.976 & \multirow{3}{*}{$\begin{array}{l}\text { Miner Slough to Cache } \\
\text { Slough }\end{array}$} \\
\hline & 2 & 0.949 & 0.811 & 0.996 & \\
\hline & 3 & 0.885 & 0.655 & 0.991 & \\
\hline \multicolumn{6}{|c|}{ Survival parameters-Continued } \\
\hline & 4 & 0.813 & 0.450 & 0.984 & \\
\hline & 5 & 0.867 & 0.587 & 0.988 & \\
\hline
\end{tabular}




\begin{tabular}{|c|c|c|c|c|c|}
\hline Name & Release & Median & $\begin{array}{c}\text { Lower } \\
\text { credible } \\
\text { limit }\end{array}$ & $\begin{array}{c}\text { Upper } \\
\text { credible } \\
\text { limit }\end{array}$ & Location description \\
\hline \multirow[t]{4}{*}{$S_{\mathrm{C} 6 \mathrm{~A}}$} & 1 & 0.578 & 0.345 & 0.823 & Cache Slough to Chipps \\
\hline & 3 & 0.832 & 0.682 & 0.977 & \\
\hline & 4 & 0.851 & 0.772 & 0.950 & \\
\hline & 5 & 0.922 & 0.837 & 0.989 & \\
\hline \multirow{4}{*}{$S_{\mathrm{C} 41 \mathrm{~B}}$} & 2 & 0.956 & 0.846 & 0.996 & \\
\hline & 3 & 0.939 & 0.758 & 0.995 & \\
\hline & 4 & 0.935 & 0.757 & 0.995 & \\
\hline & 5 & 0.893 & 0.149 & 0.995 & \\
\hline \multirow[t]{2}{*}{$S_{\mathrm{C} 42 \mathrm{~B}}$} & 1 & 0.931 & 0.759 & 0.994 & Lower Steamboat Slough \\
\hline & 2 & 0.970 & 0.889 & 0.997 & \\
\hline \multirow[t]{5}{*}{$S_{\mathrm{C} 6 \mathrm{~B}}$} & 1 & 0.858 & 0.670 & 0.980 & Steamboat Slough Exit to \\
\hline & 2 & 0.872 & 0.700 & 0.986 & Chipps Island \\
\hline & 3 & 0.810 & 0.587 & 0.974 & \\
\hline & 4 & 0.958 & 0.827 & 0.997 & \\
\hline & 5 & 0.865 & 0.704 & 0.977 & \\
\hline \multirow[t]{5}{*}{$S_{\mathrm{D} 5}$} & 1 & 0.556 & 0.382 & 0.785 & Georgiana Slough to Lower \\
\hline & 2 & 0.868 & 0.744 & 0.965 & Mokelumne \\
\hline & 3 & 0.955 & 0.863 & 0.994 & \\
\hline & 4 & 0.923 & 0.786 & 0.988 & \\
\hline & 5 & 0.954 & 0.866 & 0.994 & \\
\hline$S_{\mathrm{D} 6}$ & 1 & 0.375 & 0.181 & 0.629 & Lower Mokelumne to \\
\hline \multirow{3}{*}{$\Psi_{\mathrm{A} 1}$} & 3 & 0.988 & 0.965 & 0.997 & \\
\hline & 4 & 0.199 & 0.110 & 0.313 & \\
\hline & 5 & 0.960 & 0.887 & 0.992 & \\
\hline \multirow[t]{5}{*}{$\Psi_{\mathrm{A} 2}$} & 1 & 0.691 & 0.590 & 0.775 & Sacramento River at \\
\hline & 2 & 0.643 & 0.506 & 0.762 & Sutter/Steamboat Slough \\
\hline & 3 & 0.650 & 0.270 & 0.950 & \\
\hline & 4 & 0.751 & 0.546 & 0.887 & \\
\hline & 5 & 0.712 & 0.267 & 0.998 & \\
\hline \multirow[t]{5}{*}{$\Psi_{\mathrm{A} 3}$} & 1 & 0.729 & 0.654 & 0.798 & Sacramento River at \\
\hline & 2 & 0.700 & 0.631 & 0.764 & Georgiana Slough \\
\hline & 3 & 0.625 & 0.538 & 0.711 & \\
\hline & 4 & 0.787 & 0.705 & 0.854 & \\
\hline & 5 & 0.698 & 0.619 & 0.770 & \\
\hline \multirow[t]{5}{*}{$\Psi_{\mathrm{B} 1}$} & 1 & 0 & 0 & 0 & Yolo Bypass Entrance \\
\hline & 2 & 0 & 0 & 0 & \\
\hline & 3 & 0.012 & 0.003 & 0.035 & \\
\hline & 4 & 0.801 & 0.687 & 0.890 & \\
\hline & 5 & 0.040 & 0.008 & 0.113 & \\
\hline \multicolumn{6}{|c|}{ Routing parameters-Continued } \\
\hline \multirow[t]{3}{*}{$\Psi_{\mathrm{C} 1 \mathrm{~A}}$} & 1 & 0.204 & 0.155 & 0.259 & Sutter Slough Entrance \\
\hline & 2 & 0.195 & 0.135 & 0.265 & \\
\hline & 3 & 0.015 & 0.001 & 0.310 & \\
\hline
\end{tabular}




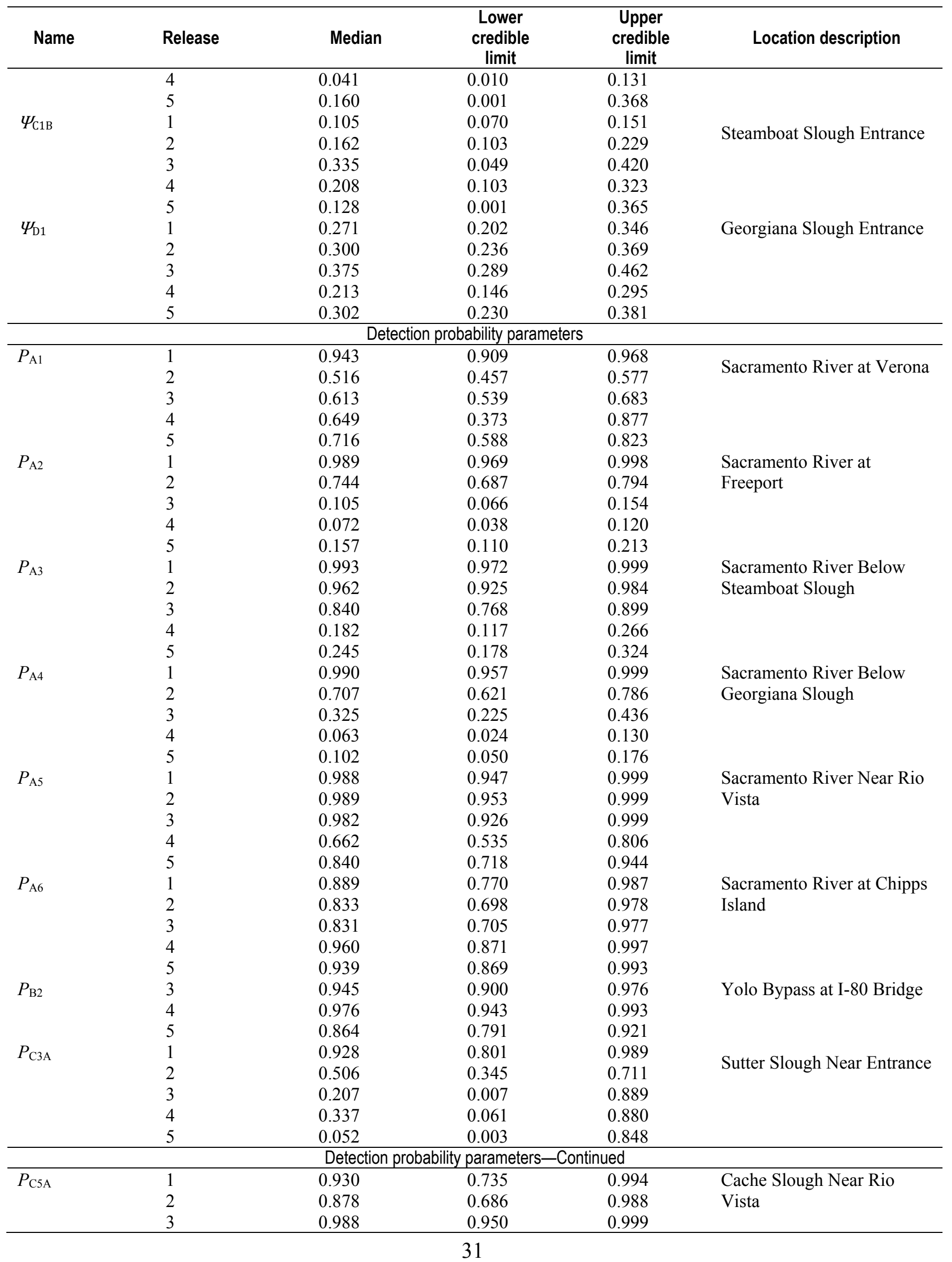




\begin{tabular}{|c|c|c|c|c|c|}
\hline Name & Release & Median & $\begin{array}{c}\text { Lower } \\
\text { credible } \\
\text { limit }\end{array}$ & $\begin{array}{c}\text { Upper } \\
\text { credible } \\
\text { limit } \\
\end{array}$ & Location description \\
\hline & 4 & 0.992 & 0.967 & 0.999 & \\
\hline \multirow[t]{4}{*}{$P_{\mathrm{C} 3 \mathrm{~B}}$} & 1 & 0.938 & 0.779 & 0.995 & \multirow{4}{*}{$\begin{array}{l}\text { Steamboat Slough Near } \\
\text { Entrance }\end{array}$} \\
\hline & 2 & 0.591 & 0.394 & 0.875 & \\
\hline & 3 & 0.067 & 0.021 & 0.359 & \\
\hline & 5 & 0.054 & 0.003 & 0.811 & \\
\hline \multirow[t]{5}{*}{$P_{\mathrm{C} 5 \mathrm{~B}}$} & 1 & 0.961 & 0.849 & 0.997 & \multirow{5}{*}{$\begin{array}{l}\text { Steamboat Slough Near Rio } \\
\text { Vista }\end{array}$} \\
\hline & 2 & 0.928 & 0.815 & 0.993 & \\
\hline & 3 & 0.872 & 0.718 & 0.969 & \\
\hline & 4 & 0.669 & 0.400 & 0.911 & \\
\hline & 5 & 0.755 & 0.541 & 0.962 & \\
\hline \multirow{2}{*}{$P_{\mathrm{D} 4}$} & 4 & 0.963 & 0.842 & 0.997 & \multirow{2}{*}{$\begin{array}{l}\text { Georgiana Slough Near } \\
\text { Entrance }\end{array}$} \\
\hline & 5 & 0.976 & 0.900 & 0.998 & \\
\hline \multirow[t]{5}{*}{$P_{\mathrm{D} 5}$} & 1 & 0.883 & 0.602 & 0.991 & \multirow[t]{5}{*}{ Lower Mokelumne River } \\
\hline & 2 & 0.954 & 0.829 & 0.997 & \\
\hline & 3 & 0.969 & 0.886 & 0.997 & \\
\hline & 4 & 0.955 & 0.828 & 0.996 & \\
\hline & 5 & 0.969 & 0.883 & 0.997 & \\
\hline \multicolumn{6}{|c|}{ Travel time parameters } \\
\hline \multirow[t]{3}{*}{$\alpha_{\mathrm{A} 1}$} & 1 & 2.356 & 2.135 & 2.589 & \multirow{3}{*}{ Sacramento River at Verona } \\
\hline & 2 & 4.338 & 3.904 & 4.778 & \\
\hline & 3 & 3.318 & 2.941 & 3.727 & \\
\hline \multirow[t]{5}{*}{$\alpha_{\mathrm{A} 3}$} & 1 & 1.494 & 1.332 & 1.661 & \multirow{5}{*}{$\begin{array}{l}\text { Sacramento River Below } \\
\text { Steamboat Slough }\end{array}$} \\
\hline & 2 & 1.370 & 1.217 & 1.537 & \\
\hline & 3 & 1.029 & 0.684 & 1.418 & \\
\hline & 4 & 0.495 & 0.241 & 0.832 & \\
\hline & 5 & 0.546 & 0.291 & 0.839 & \\
\hline \multirow[t]{5}{*}{$\alpha_{\mathrm{A} 4}$} & 1 & 0.928 & 0.802 & 1.063 & \multirow{5}{*}{$\begin{array}{l}\text { Sutter/Steamboat Slough to } \\
\text { Georgiana Slough }\end{array}$} \\
\hline & 2 & 0.822 & 0.710 & 0.944 & \\
\hline & 3 & 0.711 & 0.563 & 0.879 & \\
\hline & 4 & 0.426 & 0.223 & 0.683 & \\
\hline & 5 & 0.520 & 0.341 & 0.743 & \\
\hline \multirow[t]{5}{*}{$\alpha_{\mathrm{A} 5}$} & 1 & 1.286 & 1.096 & 1.496 & Georgiana Slough to above \\
\hline & 2 & 1.240 & 1.056 & 1.449 & Rio Vista \\
\hline & 3 & 1.025 & 0.788 & 1.288 & \\
\hline & 4 & 0.561 & 0.300 & 0.871 & \\
\hline & 5 & 0.625 & 0.397 & 0.883 & \\
\hline$\alpha_{\mathrm{A} 6}$ & 1 & 4.348 & 3.827 & 4.897 & Above Rio Vista to Chipps \\
\hline & 2 & 6.389 & 5.649 & 7.144 & Island \\
\hline & 3 & 6.458 & 5.594 & 7.392 & \\
\hline & & Trave & ameters-C & & \\
\hline & 4 & 2.163 & 1.772 & 2.590 & \\
\hline & 5 & 3.610 & 3.100 & 4.149 & \\
\hline$\alpha_{\mathrm{B} 1}$ & 3 & 1.784 & 1.550 & 2.033 & Fremont Weir to I-80 \\
\hline
\end{tabular}




\begin{tabular}{|c|c|c|c|c|c|}
\hline Name & Release & Median & $\begin{array}{l}\text { Lower } \\
\text { credible } \\
\text { limit }\end{array}$ & $\begin{array}{c}\text { Upper } \\
\text { credible } \\
\text { limit }\end{array}$ & Location description \\
\hline & 4 & 3.236 & 2.840 & 3.674 & Bridge \\
\hline & 5 & 3.385 & 2.970 & 3.831 & \\
\hline \multirow[t]{3}{*}{$\alpha_{\mathrm{B} 3}$} & 3 & 7.473 & 6.713 & 8.268 & \multirow{3}{*}{ I-80 Bridge to Cache Slough } \\
\hline & 4 & 3.329 & 2.923 & 3.768 & \\
\hline & 5 & 3.628 & 3.172 & 4.117 & \\
\hline \multirow[t]{5}{*}{$\alpha_{\mathrm{CAA}}$} & 1 & 1.520 & 1.093 & 2.002 & \multirow{5}{*}{$\begin{array}{l}\text { Sutter Slough to Miner } \\
\text { Slough }\end{array}$} \\
\hline & 2 & 1.535 & 1.083 & 2.062 & \\
\hline & 3 & 2.279 & 0.637 & 13.032 & \\
\hline & 4 & 1.178 & 0.412 & 2.520 & \\
\hline & 5 & 1.094 & 0.346 & 6.637 & \\
\hline \multirow[t]{5}{*}{$\alpha_{\mathrm{CAB}}$} & 1 & 1.630 & 0.983 & 2.443 & \multirow{5}{*}{$\begin{array}{l}\text { Sutter Slough to Steamboat } \\
\text { Slough }\end{array}$} \\
\hline & 2 & 1.327 & 0.845 & 1.943 & \\
\hline & 3 & 2.470 & 0.548 & 14.671 & \\
\hline & 4 & 1.242 & 0.287 & 7.015 & \\
\hline & 5 & 0.971 & 0.365 & 7.064 & \\
\hline \multirow{5}{*}{$\alpha_{\mathrm{C} 6 \mathrm{~A}}$} & 1 & 5.564 & 4.189 & 7.037 & \multirow{5}{*}{$\begin{array}{l}\text { Cache Slough to Chipps } \\
\text { Island }\end{array}$} \\
\hline & 2 & 8.350 & 6.808 & 10.036 & \\
\hline & 3 & 5.784 & 5.140 & 6.482 & \\
\hline & 4 & 2.749 & 2.389 & 3.140 & \\
\hline & 5 & 3.838 & 3.364 & 4.341 & \\
\hline \multirow[t]{5}{*}{$\alpha_{\mathrm{CBB}}$} & 1 & 1.313 & 0.921 & 1.762 & \multirow{5}{*}{$\begin{array}{l}\text { Upper Steamboat to Lower } \\
\text { Steamboat Slough }\end{array}$} \\
\hline & 2 & 1.223 & 0.901 & 1.601 & \\
\hline & 3 & 0.993 & 0.485 & 1.658 & \\
\hline & 4 & 0.629 & 0.291 & 1.115 & \\
\hline & 5 & 0.997 & 0.382 & 6.642 & \\
\hline \multirow{5}{*}{$\alpha_{\mathrm{CBA}}$} & 1 & 18.450 & 8.264 & 28.906 & \multirow{5}{*}{$\begin{array}{l}\text { Upper Steamboat to Miner } \\
\text { Slough }\end{array}$} \\
\hline & 2 & 27.090 & 19.353 & 34.505 & \\
\hline & 3 & 1.683 & 0.740 & 3.407 & \\
\hline & 4 & 5.616 & 0.738 & 13.455 & \\
\hline & 5 & 1.065 & 0.355 & 6.919 & \\
\hline \multirow[t]{5}{*}{$\alpha_{\mathrm{C} 6 \mathrm{~B}}$} & 1 & 4.178 & 3.380 & 5.089 & \multirow{5}{*}{$\begin{array}{l}\text { Steamboat Slough Exit to } \\
\text { Chipps Island }\end{array}$} \\
\hline & 2 & 7.713 & 6.694 & 8.801 & \\
\hline & 3 & 5.869 & 4.805 & 7.049 & \\
\hline & 4 & 2.003 & 1.477 & 2.632 & \\
\hline & 5 & 3.124 & 2.491 & 3.824 & \\
\hline \multirow[t]{5}{*}{$\alpha_{\mathrm{D} 5}$} & 1 & 1.737 & 1.256 & 2.319 & \multirow{5}{*}{$\begin{array}{l}\text { Georgiana Slough to Lower } \\
\text { Mokelumne }\end{array}$} \\
\hline & 2 & 1.878 & 1.512 & 2.268 & \\
\hline & 3 & 2.287 & 1.856 & 2.757 & \\
\hline & 4 & 1.323 & 0.967 & 1.731 & \\
\hline & 5 & 1.872 & 1.497 & 2.295 & \\
\hline \multirow[t]{5}{*}{$\alpha_{\mathrm{D} 6}$} & 1 & 6.024 & 4.322 & 7.953 & \multirow{5}{*}{$\begin{array}{l}\text { Lower Mokelumne to } \\
\text { Chipps Island }\end{array}$} \\
\hline & 2 & 18.588 & 16.171 & 21.219 & \\
\hline & 3 & 13.980 & 11.995 & 16.026 & \\
\hline & 4 & 8.211 & 6.766 & 9.772 & \\
\hline & 5 & 8.237 & 6.991 & 9.636 & \\
\hline \multirow[t]{5}{*}{$\beta$} & 1 & 1.640 & 1.499 & 1.786 & \multirow[t]{5}{*}{ Entire Delta } \\
\hline & 2 & 3.351 & 3.061 & 3.651 & \\
\hline & 3 & 3.596 & 3.277 & 3.948 & \\
\hline & 4 & 1.835 & 1.640 & 2.036 & \\
\hline & 5 & 2.392 & 2.155 & 2.644 & \\
\hline
\end{tabular}



Publishing support provided by the U.S. Geological Survey

Science Publishing Network, Tacoma Publishing Service Center

For more information concerning the research in this report, contact the Director, Western Fisheries Research Center

U.S. Geological Survey

6505 NE 65th Street

Seattle, Washington 98115

https://wfrc.usgs.gov/ 
